\title{
NAKI ISANBET'S ARTICLE “ON THE WAYS TO THE TATAR MUSIC DEVELOPMENT"(1923) AS A SOURCE OF SCIENTIFIC COMMENTATION
}

\author{
Yulduz Nakievna Isanbet ${ }^{1}$, \\ mileuscha@mail.ru.
}

\begin{abstract}
This article presents a textual scientific commentary on Naki Isanbet's article "On the Ways to the Tatar Music Development", published under a pseudonym in Kazan in 1923. It was a tribute to the memory of his elder brother who went missing during the Civil War. Our study convincingly proves that Naki Isanbet's article has not lost its relevance today. The scientist correctly identified the key tendencies in the study of Tatar folk music and outlined the ways for the development of professional Tatar music.
\end{abstract}

Key words: Tatar music, Tatar folk song, Naki Isanbet, A. Eichenwald, S. Gabyashi, S. Saydashev.

\section{Introduction}

The folk melodies of the Kazan Tatars, recorded and adapted for a symphony orchestra by Anton Eichenwald, were first performed on August 3, 1923 at an oriental music concert, held in the Red Army Palace (now the K. Tinchurin Theater). The concert program included Tatar songs "Kaz Kanaty" ("A Goose Wing"), "Okop kee" ("A Trench Song"), "Salkyn chishmə" ("An Ice-cold Spring"), "Meslimk" ("Muslima"), "Tugan silt" ("Our Motherland"), and "Gazizk baldyz" ("Gaziz's Sister-in-Law”). It was the first symphony concert of oriental music in the history of Tatar music. The performers of Tatar folk songs, Sara Sadykova, Khakima Chamaeva, and Yarulla Chamaev, took part in it (Fig. 1).

Among newspaper publications, devoted to the symphony concert of oriental music [K kontsertu dirizhera Eikhenval'da], [Simfonicheskii kontsert TatMuzo], [Tatar жyrlaryn muzykaga...], [V. Gn.], [Zenz], [Simski, 1923], [Simski, 1928], [Sh. G.], [U-v], [Eichenwald], N. Isanbet's article "On the Ways to the Tatar Music Development" ("Tatar Muzyksyn Eshləu Yulinda") stands apart. It was published, as was typical of all his journalistic materials of the 1920s, under the pseudonym Z. Zakir [Zakir] (see: Appendix 1). The young poet N. Isanbet visited Kazan on his way to Kharkov University. By this time, the main themes and trends of his work had already been determined. From an early age, he was interested in Tatar folk art. The concert of A. Eichenwald and new personal impressions provided him with additional information for thinking about the fate of Tatar music in the past and in the future.

\section{Materials and research methods}

In the appendix to this article, N. Isanbet's work is given in the original language, since we encountered objective difficulties in translating it from Tatar into Russian. Certain imperfections of the text can be explained by the fact that this material was published without the consent of the author and without his proofreading, as the article was prepared for publication after the poet's departure from Kazan. Moreover, in his work N. Isanbet used the terms that have no equivalents in the Russian language. When quoting N. Isanbet, we were forced to resort to approximate paraphrasing or use a simplified literal translation. In some cases, variant meanings of the translated words are given in brackets in order to facilitate the understanding of the article. Some terms are always translated in the same way: "Kyr" - "song" (and only once, its context-based meaning is "folk vocal music"), "kөy" is translated as "koi", "muzykany eshləy" - as "the formation of music; composing music; musical creative works", "madəniləshtery" - as "professionalization; creating professional music". The word "моң" is used by N. Isanbet in two meanings:

\footnotetext{
${ }^{1}$ The author had passed away before she saw the final version of the accepted article, so M. M. Khabutdinova, an executive editor, has built the structure of her article in accordance with the requirements of the journal.
} 
1) "a melody", but not any melody, only the one possessing the quality described by the Tatar word "моң' (that is, in this case, "моң" meaning "ozyn key", and the "melody", respectively, meaning "a lingering song", or "uzun kyui"); 2) a definition of a specific emotional and psychological state. In the latter case, due to the lack of a Russian equivalent, the word is given in the Tatar language (the interpretation of the word "моң" will be discussed in more detail later).

\section{Discussion}

$\mathrm{N}$. Isanbet's article was published after the first responses to the concert appeared. No doubt, the author had thought over more than once about what was said in the article. Surely, in A. Eichenwald's work, he found answers to some questions that had tormented him, and it took time to look at these issues from a slightly different angle to formulate his point of view on the prospects for the development of Tatar music.

Since the fall of the Kazan Khanate in 1552, for four and a half centuries, the Tatar people actually had no chance even for the elementary development of their spiritual culture. Only literature struggled to maintain its positions. It was after the famous "Imperial Manifesto on the Improvement of the State Order" of October 17, 1905, which granted democratic rights and freedoms in Russia, that some forms of concert and theatrical activity, characteristic of European and Russian culture, began to gradually develop in the cities with the Tatar population. Theater companies, small musical groups and individual performers began to apply for citizenship and, albeit sometimes with great difficulty, got permission to perform in public. Amateur art entered the path of professionalism.

But if the emerging Tatar theater was rapidly developing its own repertoire (including translated works) created by Tatar playwrights, then music, in this respect, lagged far behind. The few, essentially amateur, works of Tatar authors were in short supply; therefore, it was folk music that formed the basis of Tatar performers' musical repertoire. It was folk music in its pure form and in simple arrangements for singing with accompaniment, or music for individual instruments and ensembles. But even the elementary adaptation of folk tunes turned out to be a complicated task and not only at the initial stage of the professional music formation, as time has shown.

The Tatars did not have their own composers with the necessary professional qualification. They still had to be educated, to pass all the long stages of musical education from primary to higher levels. However, education alone, moreover crash courses, did not guarantee the creation of music that could be perceived precisely as nationally Tatar. What is more, no one clearly understood what was to be done to achieve this goal. All that remained was to somehow focus on the traditions of folk music, which so far had not been studied yet. Tatar musicians of that time, those who grew up on folk music and perceived it not with their mind, but with their soul, did not necessarily need scientific knowledge about it. However, it was necessary for composers of other nationalities who tried to work in the field of Tatar music and for future educators of both Tatar composers and performers, especially singers. To understand the specific features of Tatar music, they needed both time, which they did not always have, and certain efforts. Some of the authors of new works proceeded from well-known traditions, others preferred to ignore, not to notice them. Everyone acted to the best of their talent, knowledge, and responsibility and with different results.

Monophonic folk tunes and new authors' melodies, spiritually connected to them, were hardly amenable to harmonization, associated with the introduction of polyphony into Tatar music, the process inevitable in striving for its Europeanization. Without polyphony, one could not expect the development of either opera, ballet, or other European academic genres, which the figures of Tatar culture dreamed of. In N. Isanbet's opinion, A. Eichenwald came closest to an adequate polyphonic arrangement of Tatar tunes.

The article has two parts. The first of them is devoted to the issues related directly to the work of A. Eichenwald, the second is about the national originality of Tatar music and some issues of the further development of Tatar professional music.

Beginning the article with the assumption that "the recent Tatar symphony evening, conducted by the venerable composer A. Eichenwald, triggered new thoughts about Tatar music and its future in the minds of many music lovers, in particular," and finishing the article with the words that it was time to seriously discuss the development of Tatar music, that "I especially want to hear the opinion of musical figures, who are accustomed to keeping their work away from newspaper and magazine pages," N. Isanbet, nevertheless, apparently did not hope for a broad discussion of the issues he raised. Comparing different points of view, he discussed them himself. 
Both positive and negative opinions about the current state and future of Tatar music, given by the author, were not generally accepted or expressed by someone publicly, but were formulated as possible ones by $\mathrm{N}$. Isanbet himself. At the same time, N. Isanbet did not argue with his potential opponents who were critical of Tatar music (it is not accidental that the title of the article has the note "Instead of debates," but not, for example, "As a matter of discussion"), and did not reject their point of view as antagonistic, hostile, but usually analyzed what it was caused by. N. Isanbet believed, in a number of cases, there were real grounds for expressing opposing views.

The author of the article expressed confidence that the emergence of professional Tatar music in the near future was historically inevitable, although he stated that "until now, forecasts about the future of Tatar music have been extremely pessimistic". $\mathrm{N}$. Isanbet connected the future progress of Tatar music with the progress of Tatar culture in general.

He wrote that, in contrast to pessimistic forecasts, "the belief that, as the economic and political growth of independent peoples increases and develops, their languages, literature, theater, and music, the music of the Tatar people, whose other branches of culture are gradually maturing, will also someday grow up and come of age. Because, if music is a part of art, then art itself is a branch of culture, which can grow and develop only if all its individual elements are healthy. Like other branches of Tatar culture, its art is forced to go forward only by being wound on a common historical axis (in a common historical team only)", thus, N. Isanbet pointed out the first two steps that had already been taken in this direction in music [Zakir].

He believed the first step to be the collection and musical notation of folk kyuis scattered in different areas (in the personal library of N. Isanbet himself there were notation editions of recordings by S. Rybakov, M. Sultanov, M. Berg, and publications of post-revolutionary literary-musical and youth societies from Kazan, Orenburg, and Ufa well-known to the Tatar intelligentsia of that time). The second step, from his point of view, was the work of the authoritative musician Sultan Gabyashi who was the author of a) new musical works, partially woven from Tatar motifs, b) kyuis for a number of stage works, c) adaptations of folk songs for choral singing, based on research into sound composition, time signature, and metrics.

$\mathrm{N}$. Isanbet thought that the young musician Salikh Saydashev was also moving in this direction, as if anticipating subsequent events, since Saydashev, who had worked in the Tatar theater from the fall of 1922, had not yet created his own musical pieces and simply used folk melodies in his theatrical productions.

At the same time, N. Isanbet did not overestimate his contemporaries' merits and admitted that "all these steps towards the professionalization of Tatar music were insufficient, it was a half measure. Although they were based on the desire to fit Tatar music into scientific, creative forms in accordance with the musical canons common to other peoples, the thing that struck most was the unconvincingness of these steps and the helplessness of the methods employed. It might be due to the fact that our professionals were not sufficiently armed with theoretical and scientific knowledge" [Zakir]. Since N. Isanbet clearly spoke not only of the "two steps" he was considering, but also about "all these steps" ("lukin bu adymnarnyң həmməse də", not "lukin bu adymnar", or "lukin bu ike adym da"), here, he apparently made a generalized objective assessment of all the previous experiences of collecting and composing Tatar music.

In the pre-October period, Tatar folk music was collected, processed and published, except in the case of M. Sultanov, not by Tatars, but by musicians of other nationalities, which $\mathrm{N}$. Isanbet considered to be historically justified, although these recordings and arrangements did not always correspond to the folk originals. He did not doubt they had every right to work in the field of Tatar music. "Since the musical cultures of different peoples, as well as specific branches of culture, are not separated from each other by strong barriers, there are many common ties between them; thus, when the music of each cultured nation enters a period of its intensive development, no evidence exists in history of its independent development. Therefore, if recognized figures of Italian music could work to lay the foundations of French music, then German composers could just as easily master Russian music and be of great use to it. Without a doubt, we, of all others, cannot sit on the sidelines and not follow this tradition. This would not surprise anyone in this country either" [Zakir], - he thought (however, he was slightly mistaken about the latter).

In our time, Tatar music lives independently and stands out of sight of Tatar intellectuals. But from the beginning of the 1920s, for about half a century, the public was keenly interested in introducing serious genres into Tatar music and in adequately performing the works of Tatar music, especially those in which a folk song was used as a 
theme (this technique was characteristic both of the works of Tatar composers and of Russian composers who tried to compose Tatar music) by singers and instrumentalists with a professional (especially conservatory) education. To the national perception of the Tatar audience, many works and the manner of their performance were nationally uncertain, or even completely alien, which was usually explained by the fact that Jews and Russians spoiled Tatar music because they did not understand it. There were many things that jarred on $\mathrm{N}$. Isanbet: in the main, he did not like the personnel policy of N. Zhiganov, who was both the rector of the conservatory and the chairman of the Union of Composers, that is, the sole ruler in the sphere of "serious" music in the republic, but N. Isanbet never measured the degree of national adequacy, "Tatarness" of music, or its performance only by the nationality of the musicians.

As can be seen from some of the N. Isanbet's quoted statements, he was objective and noticed the merits and demerits not only of Tatar and nonTatar composers, but even of Tatar folk music itself, which did not occupy a huge place in his soul. The article presents two examples of opposite results achieved by representatives of Russian culture, working with Tatar tunes, whose work took place literally in front of the readers' eyes. The first of them concerns the activities of the composer and collector of folk songs Ya. Prokhorov. There is information that after the October Revolution he did a great job collecting songs of the peoples of the Volga region. In early 1920, Ya. Prokhorov came to Kazan to work in the Music and Ethnographic Department of the Central (Higher) Oriental Music School. So far as N. Isanbet called him "one of the Kazan professors most familiar with oriental music", the composer left Kazan after receiving a professorship (if he really had one), that is, after May, 1921, when the School was transformed into the Oriental Conservatory. In the same 1921, he began his work at the Moscow State Institute of Musical Science (SIMS) [Muzykal'naia, entsiklopediia, col. 474], where A. Eichenwald was also invited.

Whether following the instructions of the SIMS, or according to the proposal of the People's Commissariat for Education of the TASSR, but in 1922, Y. Prokhorov went on an expedition to collect Tatar musical folklore. As the newspaper "Tatarstan" announced, on November 3, 1922, the Tatnarkompros Scientific Center planned "a meeting of oriental art workers to listen to new recordings of Tatar folk songs", among them 16 songs recorded by Ya. Prokhorov [Tatarstan, 1922], [Moshkov]. Six Tatar folk songs, harmonized by him, were published by the Central Eastern Music School earlier, in 1920. Ya. Prokhorov was known to the citizens of Kazan for his public appearances as a musical ethnographer.

Assessing the results of his activities, N. Isanbet noted that in recent years V. Prokhorov made many attempts to work in the field of Tatar music, but the achieved result showed that the Tatar "моң" would not bow down to him.

N. Isanbet did not explain V. Prokhorov's failure by the fact that he, not being a Tatar, was unable to comprehend other nation's music in principle, he had a different explanation. He believed that, on the one hand, the shortcomings of Tatar music itself contributed to the failure; it was its immaturity, uncultivatedness, its being in the state that made it too difficult for other peoples to understand; on the other hand, it was the composer's formal attitude to the matter, his superficiality. "Instead of focusing on natural specific properties of a Tatar song while processing it, this professor attached greater importance to the conventional dress of European music and general musical technology. In the kyuis, processed by him, the main coloring of the Tatar tunes was greatly distorted, and the general technical means that he used had little to do with the beautiful tunes", was N. Isanbet's opinion [Zakir].

As for Eichenwald's experience, N. Isanbet found it successful, evaluating it as a victory: "Although Eichenwald himself is of a different nationality, his works demonstrate that he correctly understood the originality of the Tatar songs and their basic nature. In his songs, the Tatar "моң" is reproduced with very minor errors. Moreover, when he, using the main melody as a fundamental basis, colors it according to the rules of music theory, the main thread line is not broken, and the numerous patterns do not lose their connection with the basic fabric. In short, the relationship between countless threads, voices, and tune steps is not destroyed. As a result, in their natural state, such songs as "Salkyn chishmu" and "Tugan il" are so monotonous and tedious that this fact cannot but attract attention; however, when properly tinted, dressed and made up, they become attractive, and to the stunning sounds of a symphony orchestra, composed of many instruments, they sound purely Tatar, harmoniously, representing a single whole" [Zakir].

A. Eikhenwald attached great importance to the way his recordings and adaptations would be 
perceived by folk performers themselves, he sought their approval; that is, when processing folk tunes, he based his work not on the bare teaching rules of harmonization, but on the desire to make them sound natural to the Tatar listener's ear. Let me remind you how, in 1926, he described to the correspondent of the Parisian newspaper "Days" the process of working with folk material: "The processing and harmonization of the recorded material was a very hard job. At first, I worked according to all the rules of counterpoint and European harmonization; then, I invited the connoisseurs of the song of this nationality and played these songs in front of them to the piano. And for the most part, I heard the same final verdict: "not our music!"... Some things had to be redone 30-40 times - until finally they stopped saying "not our music!" All the work had to be done purely empirically. In the end, I seemed to have caught the characteristic features of their harmony ..." [Eichenwald]. Probably, this was the only correct way, requiring a lot of perseverance and time, the way of mastering a culture that was initially alien.

$\mathrm{N}$. Isanbet highly appreciated the result of A. Eikhenwald's work on Tatar folk music. He noted: "True, his music is sometimes inexact, it abounds in purely technical devices, in some places there are problems with accurate natural sound reproduction. Still, firstly, we can say that this is the first experience of processing Tatar tunes in this way; secondly, to a certain extent, we should take into account the fact that the composer belongs to a different nationality; thirdly, in the powerful orchestra, performing the song, there is not a single Tatar who would feel and perceive these tunes with their soul. But one thing is clear: this experience has clearly shown that Tatar music is capable of infinite progress, that it can be draped in a form that will not be shameful to demonstrate on the international musical maidan (arena), on the maidan of Western music characterized by a high professional level; that we need dedicated professionals, music-loving public figures, schools and organizations to achieve this aim" [Zakir].

$\mathrm{N}$. Isanbet believed it necessary to continue the work in the direction set by A. Eichenwald, expanding the road he had chosen.

One professionally qualified composer would not solve all problems. In any art, especially in such as immature and sedentary Tatar music, one single person could be responsible for only a very small part, was N. Isanbet's opinion. From his point of view, in order for the work to be more effective in the future, it was especially important that national musicians should get down to business, and Eichenwald's works could serve as a guideline for them. "For our professionals like Gabyashi and Saydash, who, so far, have been diligently looking for ways to develop Tatar music, putting a lot of effort into their searches, Eichenwald's works should facilitate this search. If, having agreed, they could work together following this path, it would be a particularly good omen that could ensure the achievement of even more fruitful results" [Zakir]. N. Isanbet hoped the Tatar musicians would join their efforts and expand their activities in this field.

Dedicating the second part of the article to the prospects for the development of Tatar music in the new conditions of post-October life, N. Isanbet considered them in close connection with the life of the people, their needs and traditions of their musical creative work. N. Isanbet found it necessary to preface the conversation about the professionalization of Tatar music with the following questions:

1) who was this music intended for?

2) what should it be like?

And without any, as he called them, "preliminary tricks" he declared: 1) for the people and 2) fundamentally new (revolutionary). In his own work, N. Isanbet was a consistently and convincingly democratic person, he called for the creation of music that was understandable and accessible to the people. In his opinion, this type of music should avoid unnecessary tricks, the dominance of musical technology, and blind adherence to all the guidelines and rules of music theory: "In the field of music, as in all other branches of art, we, basically, adhere to creativity, which is close to the people themselves. If theater, painting, poetry, sculpture, taken from life, from among the people themselves, are to develop in close connection with them, music, too, cannot but enter the framework of the same canon.

Based on this, we urge: let the further work at the musical front and on the systematization of Tatar songs never lead to breaking the relationship between people and music, as is typical of Western music, which is very far from the people as it is generated only by the fantasies of individuals, or built, like a structure, with the help of schematic installations of abstract music theory; so when we lay the foundation for composing songs and music for the people, let the share of technical devices in music be an additional (auxiliary) application, sort of a decoration ... 
As mentioned above, there is a fear that if we openly highlight this very theory, Tatar music will always stay far, far away, without its own fate in life, without any hope for the future" [Zakir].

Isanbet considered democracy to be important for music; in particular, because he believed music to be one of the most powerful means of educating a person: "No matter how much spiritual food some meaningful scientific discussions may provide for a person, a good performance of a welldone music piece will leave an even more profound impression. Of particular importance is the formation of people's feelings, the upbringing of their spiritual forces. In our life, built on a new basis, special attention will be paid to educating the people in this regard" [Zakir].

Emphasizing the importance of this issue for modern Tatar reality, N. Isanbet discussed two issues that were significant for educating the younger generation, one of them concerned the past traditions of Tatar music, the other - its future new trends, both of them - the people's worldview. In this perspective, these issues had never been considered either before, or after $\mathrm{N}$. Isanbet.

The language of Tatar music at the beginning of the $20^{\text {th }}$ century was the language of folk songs. What direction the Tatar composers' work would take, whether they should rely on the usual folk song traditions or create their music outside them, how to introduce polyphony of the Western European or Russian type into a monophonic folk melody - all these issues were to be empirically established. As the creative practice had shown, the music by young Tatar composers, based on the mechanical use of other people's experience, was rejected by the Tatar audience, who, in most cases, did not want to mistake new compositions for Tatar music. But Russian listeners, in their turn, were not close to either Tatar folk music or the works of Tatar composers.

$\mathrm{N}$. Isanbet explained the failure to understand, and in some cases rejection of Tatar folk music by listeners of other nationalities by certain specific, purely national features of folk music itself, as well as certain conditions of its existence. But he did not share the opinion of his contemporary musical experts in understanding what qualities characterize Tatar music in the first place and what determines its face.

In Kazan musical circles, the main feature of Tatar folk music was considered to be its reliance on non-half-tone (angemitone) pentatonic, or Chinese (Scottish) scale after the article "Five-sound non-semitone scales in Tatar and Bashkir folk mu- sic and their musical theoretical analysis" by the violinist, composer and researcher of Tatar and Bashkir folk music I. Kozlov [Kozlov] was published in 1928 in Izvestiya of the Society of Archeology, History and Ethnography at the Kazan State University.

We do not mean to say that before this publication, no one knew anything about the pentatonic scale in Kazan. The presence of the "five-tone scale" in Tatar songs was noted by S. Rybakov [Rybakov], the famous Russian ethnographer and collector of folk, including Tatar, songs [Moshkov]. The initial information about the pentatonic scale and, perhaps, about the Russian sholars' works, dedicated to it in the second half of the $19^{\text {th }}$ century, must have been known to teachers and graduates of the Kazan Musical College. When the Central (from November 1, 1920 - the Higher) Oriental Music School (from March 1922 - the Eastern Conservatory) was opened in Kazan at the end of 1919, a music and ethnographic department was formed under the supervision of famous Moscow ethnographers, it had a musical and ethnographic association, whose members were engaged in extensive collecting and educational work. The planned series of works at the department was opened by P. Nikolsky's [Nikol'skii] "Synopsis on the history of folk music among the peoples of the Volga region", published in 1920, which, in particular, touched on the role and significance of the pentatonic scale in the musical heritage of the Volga peoples. There is information that this work was also published in translations into the Tatar and Chuvash languages. Among the 11 scientific reports, delivered at the meetings of the association in 1921, there were reports by I. Kozlov "Folk Music of Northern Muslims" and "Five-sounding Non-Semitone Scales in Tatar and Bashkir Folk Music and Their Musical Theoretical Analysis", based on the aforementioned article [VaidaSaidasheva]

In the opening speech at his concert, A. Eichenwald said that "all Tatar old songs have a certain musical texture and structure on a kind of a five-note scale (akin to the Chinese one)", revealing the existence of the pentatonic scale to the most ordinary audience, moreover, the Tatar one. Nevertheless, the figures of Tatar music started talking seriously about the pentatonic scale only after the publication of Kozlov's article. Apparently, this was due to the fact that, along with the statement, declaring the pentatonic type of Tatar folk music and general information about the pentatonic scale, Kozlov gave specific examples of 
pentatonic scales, analyzed their interval composition and moods, considered the issues of chord formation and the setting of key signs (determining the tonality), that is, it would seem that the article provided some direction for the practical use of the pentatonic scale. At the same time, for scholars, Kozlov's article suggested new ways of manipulating with pentatonic scales, of interpreting them, and of making terminological descoveries. In a word, there was something to talk about.

In his answers to the questions of the "Yanalif Magazine" "On Tatar Music" in 1931, S. Gabyashi [Gabashi] was the first of the Tatar musicians to raise the problem of the pentatonic scale. Practical and theoretical interest in pentatonic music considerably increased after the opening of the Kazan Conservatory in 1945, where Tatar composers were educated on a regular basis. In the pentatonic scale, they began to see not only the main, but the only noteworthy feature of Tatar music. Although, at one time, A. Eichenwald noted that the pentatonic scale did not prevent Tatar music from being figuratively rich and interesting ("Despite the seeming, at first glance, poverty of this five-note scale, the songs of the Kazan Tatars are so diverse that one would be amazed: how folk art happened to achieve such combinations with such a small number of sounds and created a variety of melodies, deep in content and mood, from the saddest to the most dashing and cheerful ones" [Eichenwald]), in the 1950s the attitude to it was rather negative.

The pentatonic scale, as a relic of past eras, was made responsible for the fact that before the October Revolution the Tatars did not have professional music, that Tatar folk music was monophonic, boring and monotonous, that Tatar motifs, as a thematic basis for large forms, were not capable of development, moreover, cultured people should not listen to pentatonic Tatar music, because it was unbearable. The pentatonic scale inhibited the development of Tatar professional music, therefore we should get rid of it, triumph over it, eradicate it, enriching it with semitones, replacing it with the diatonic scale, enriching it with chromatisms, so it was best to abandon it altogether in favor of the major-minor tone of the $19^{\text {th }}$ century. Surprisingly, such thoughts were expressed not in the early 1920s, when Tatar professional music was in its infancy, but in the middle of the century, when Tatar music could be proud of its achievements not only on a national scale, but also, taking into account at least F. Yarullin's ballet "The Shurale", at the international level.
Tatar folk music is really pentatone. But its national originality is not the pentatonic scale as such. The angemitonic pentatonic scale, known since ancient times and characteristic of very many European and Asian peoples, has no nationality at all. The music of each of these nations is individual and easily distinguishable from the pentatonic music of any other nation. Kazan public and Kazan musical figures could see this for themselves while attending the concerts [Kazan] of three international composers' conferences of the "pentatone zone" (Tatarstan, Bashkiria, Chuvashia, Buryatia, Yakutia, China, Korea, Mongolia, etc.). In the same way, it is not difficult to distinguish the nationality of diatonic, major-minor or even dodecaphonic works of composers from different European nations (compare, for example, the music of Germans, Italians, Czechs, etc.). The point is not their sound or modal systems, but the people's national character, psychology, mentality, emotional and psychological state at a given historical period of time and their reflection in music.

To make the Tatar people believe that some melody is their own, the pentatonic scale alone is not enough. The chant must be in tune with the soul of the people, otherwise they will remain indifferent or reject it, regardless of whether it is pentatonic or not. Unlike professional musicians, ordinary people are unaware of the existence of any sound systems, they are far from consciously "using" some well-known techniques, they simply pour out their souls in music, intuitively finding the necessary musical means. Folk music is born not by a template, but by inspiration; although composers' music can sometimes be constructed according to the well-known rules, described in textbooks, one cannot expect this from the folk.

Isanbet did not explain by the limited capabilities of the pentatonic scale the assessment given by "foreign nations to all Tatar songs as being similar to each other, monotonous, plaintive, dreary sound combinations" and the disbelief in the future of Tatar music, expressed not only by representatives of other nations, but also by many Tatars, but by the fact that in the periods preceding the concert of $\mathrm{A}$. Eichenwald, folk music reached the audience "only in its natural form, in the way it was preserved among the people". However, not everything is preserved among the people. "Many songs and tunes were crushed by the wheels of history and disappeared, and the surviving part perished in the tragedy of enslavement that followed the Tatar crisis (meaning the fall of the Kazan Khanate. - Yu. I.), to say the least", asserted N. Isanbet [Zakir]. 
What the music of Volga Bulgaria or the Kazan Khanate was like, we may only try to guess (once, in a personal conversation $\mathrm{N}$. Isanbet mentioned a surprisingly bright sunny tune, preserved from the Bulgarian times, which, despite its originality, Tatar musicologists usually classified as an absolutely different type). In the following centuries, the Tatar people "considered their songs and music to be their life companions so that through them they could pour out grievances arising from their bitter fate, and we must treat this fact with caution and care", said N. Isanbet [Zakir].

The poet and folklorist wrote: "That part of Tatar music, which, having acquired citizenship, was kept in the people's memory, was imbued with immeasurable hopelessness, sorrow, bitter crying (caused by their dissatisfaction with life). We inherited these characteristic features from our merciless history: first, existing as victims of the struggle for the throne of our own khans; then, becoming woeful victims of Russian imperialism. Over the past three to four centuries, the Tatar people had to quench their thirst only with such bitter drinks" [Zakir].

It was not the pentatonic scale that made the Tatar tunes mournful, but the deep wound existing in the soul of the people for centuries. The pentatonic scale, along with the special forms of song and instrumental (violin) chants, and the characteristic timbre of the voice ("tearful", but without strain) inherent in many folk singers, helped to reveal the feeling of inescapable pain with which the concept of "моң" is inextricably linked.

In academic music, there is no notion of this concept in the sense this word is used in the Tatar language. However, Tatar music is hardly absolutely unique in this respect. For example, "моң" is also characteristic of the lingering songs of the Bashkirs, the people closest to the Tatars. But, in comparison with Tatar songs, the songs of the Bashkirs are distinguished by greater breadth and some kind of feeling of inner freedom. N. Isanbet explained this by the fact that the Bashkirs lived in large areas surrounded by the beautiful Ural natural landscapes, which gave them strength. Even on a superficial acquaintance, a kind of "моң" is felt in the music of the American blacks (African Americans) or in the timbre of some oriental instruments (for example, the ukulele). A special study of “моң", for sure, will bring it to light in some other peoples' folk music, whose work is still little known.

Russian musical figures and Russian listeners of that time perceived Tatar tunes as monotonous and identical pieces of music because they did not know the feeling of the Tatar "моң", moreover, they did not appteciate its shades. Conswquently, quickly getting tired of the music, incomprehensible in mood, they saw the root of evil in the pentatonic scale.

We might come across the correct use and correct interpretation of the word "моң" in some works on Tatar music. But since these works are written in Russian and usually by professionals who have a poor command of the Tatar language, such a probability is small. Not even interested in the meaning of this word in the Tatar language, many of these professionals painstakingly try to give it their own speculative interpretation, usually proceeding from the nature of the music and those musical and expressive means that, in their opinion, make up this "моң".

G. Sabirzyanov, for example, assured the readers of the "Tatar Encyclopedic Dictionary": "Моң is a term that defines the national flavor of the Tatar spiritual culture, a specific feature of the worldview, an emotional state of suppressed sadness, expressed in the variation of shades of basic intonation. M. is especially vividly manifested in music, poetry, and painting" [Tatarskii entsiklopedicheskii slovar', p. 365]. Such a definition can be criticized at large as a collection of words. But the point is not that such different phenomena as the "color" of culture, a feature of the worldview and an emotional state cannot be "expressed in variation" of something, and it is not that the author, apparently, did not realize what intonation was meant - the intonation of speech or the musical one (and what about painting, which is devoid of intonation?), and not even that it is impossible to vary the "shades" of the basic intonation (if we are talking about a melodic device). The thing is that the author considers "моң" to be a variation, that is, a compositional technique. We can come across this interpretion of "моң" as a means of musical language and form creation in the works of other authors.

In fact, "моң" is a feeling, more precisely, one of the human feelings inherent in the nature of a Tatar person. At certain stages of the historical development, this feeling became all-consuming, leaving its imprint on all aspects of the Tatar people's life, including their literature and art. In music, it obviously manifested itself in Tatar folk lingering songs - "uzun kyui" (Tatar: “озын көй”). This is probably why Kazan musicians, primarily musicologists, treating limgering songs abstractly, 
outside the cultural and historical context, consider "мон" to be a musical term.

The exact and full translation of the word "моң" into Russian is complicated for objective reasons. In translations of Tatar literary texts, the equivalent of different contextual meanings of this word are usually found. But in the sense that it is used in relation to music, the word "мон" is untranslatable into Russian (and, apparently, into most languages of other peoples), because other people do not know the feeling indicated by this word. It is difficult to explain its meaning not only to Russians, but sometimes to some modern Tatars, because a person cannot simply through words understand what, for example, "pride", "conscience", "love" or other feelings mean, if he or she has never experienced them. ("There is no such thing as "моң", but there is such a zest that adorns the melody", A. Lehman, a professor of the Kazan Conservatory, used to repeat). However, a sensitive, empathetic person, who not does not only communicate with the bearers of this feeling, but also delves into their life circumstances, will be able to experience this feeling with his/her heart.

Concepts or terms that are absent in a certain language are usually used as borrowed words reproduced in transcription. Two sounds out of three that make up the word "моң" are phonetically alien to the Russian language. According to the rules of recording Tatar sounds with the letters of the Russian alphabet (Tatar "o" = Russian " $u$ "; Tatar " $\mathrm{H}$ " = Russian "ng"), transliterated "моң" looks like "mung" (or, at the worst, "mun"), which is not customary and has not yet been used much. But there is nothing you can do about it. As there is no equivalent of this word in Russian, when writing or speaking, we can choose between transliterated "mung", or the word "моң" in Tatar. The variant ("mon"), found in Tatar Encyclopedic Dictionary, is anti-scientific.

Human feelings are socially and historically conditioned, like the human personality itself, which changes in the course of history.

Interesting observations about the essence of mon are contained in N. Isanbet's article on the work of Farida Kudasheva (1959):

"When our people sing a song, they expect the singer, along with the melody, to voice their soul with the richness of feelings inherent in it, i.e. to demonstrate the inner soul of the melody in its movement and dynamics. This mysterious "тоң" should be felt in the interweaving of the techniques, permeating the soul and the traditions. If so, then it is impossible to interpret "моо" simply as sorrow and longing, as some people understand it. It is used here in the meaning of "need". That is, "тоң" realizes the spiritual need of the people" [Isanbet].

It is necessary to discuss one more feature of "моң" in music, which N. Isanbet noted: a lingering song was a companion of the people during the period of sorrowful colonial life. The people not only poured out their "woeful complaints about their bitter fate" through it, but also found consolation with its help. Lingering songs, especially the Bashkir ones, are very beautiful, they have a very strong aesthetic element. It is "моң" that is the most characteristic feature of a carefully preserved lingering song, with it the concept of Tatar folk musical classics is primarily associated. The music was thought to be non-Tatar not because it used semitones but because it was devoid of what is called by the word "моң".

\section{Results}

In spite of his love for Tatar lingering songs and his high opinion of their role in the life of the people in the past, Isanbet did not see any special prospect for their existence in the future, because with the October Revolution the life of the people changed dramatically, the historical conditions of their existence changed. That is why, he believed, in the future, Tatar music should be "revolutionary" ("inkyilyabi"), but not in the sense that "it should reflect the ideas of the October Revolution specifically", but meaning that "it should radically change, become new". In translation the use of the definition "innovative" instead of "revolutionary" would not be entirely appropriate here, since in Tatar musicology it has a somewhat different meaning.

The articles and studies, devoted to innovations in Tatar music, are usually not about a genuine renewal of Tatar music from the inside, but about Tatar composers' use of musical and expressive means, forms, and genres of classical and modern music (sometimes it became an end in itself) previously not used in Tatar music. The evolution of Tatar music was viewed rather from a pedagogical standpoint - as a step-by-step process of professional education, knowledge acquisition, and improvement. An innovator in something (using a semitone or a dominant seventh chord, writing a quartet or an opera, using the form of a sonata or a three-part fugue, etc.) was the one who was the first to transfer to the Tatar soil some of the discoveries of distant and near predecessors. However, from this perspective, virtually all music, writ- 
ten by Tatar professional composers (at least until the middle of the $20^{\text {th }}$ century), was innovative for Tatar art. As for the further renewal of Tatar music, it was largely based on borrowed creative ideas. What was called innovation from the point of view of the Tatar music development, in the view of European music would be called the creative development of its traditions. This accelerated path of professionalization was followed by composers of all union and autonomous republics of the USSR, which did not have professional music of the European type before the revolution.

But the language, forms and genres of Tatar professional music have a lot of really new, original, moreover, our own things, created precisely by Tatar composers, but remaining out of sight of researchers who do not seek to go beyond the usual framework of educational and pedagogical problems. In particular, attention should be paid to the emotional-figurative enrichment of Tatar music, achieved sometimes with the help of the most common musical means and techniques, which have long been discussed in science. The author of this work used to note that S. Saydashev introduced joyfulness and optimism into Tatar music, R. Yakhin introduced excitement (N. Zhiganov drew my attention to this feature of Yakhin's music), but, on the whole, the problem remains unexplored.

When speaking about the need to radically change Tatar music, N. Isanbet had its content in mind. He was worried that "the children of the nation, growing up in the free space of a new free life as the sole owners of all its resources" entered a new life, having in their heritage only the music of the colonial time. Its characteristic features prevented it from "being in harmony and unity with the new conditions of a free life", he noted. The modern generation needed ebullient life (khyat), freedom, relaxedness (irek), prowess (жitezlek), joy (shatlyk), conviviality (bəirəm), external manifestation of feelings, splashing out emotions, and triumph (nəmesh).

However, our music could not do this. Therefore, cultural figures, working on Tatar music, should focus on this feature of the real state of affairs in the future.

Among Tatar songs, only takmaks and bayts, which are few in number, lack these prevailing original features. Is it really possible that numerous takmaks and bayts, existing in former times and lost for historical reasons, forgotten, their traces gradually obliterated, that they can be found
Therefore, in the future we will have to create this kind of music ourselves.

Folowing this path, we do not have to reinvent the wheel. Because, no matter how few of them can be found, one cannot say that we have absolutely no songs and tunes in which the spark of life has not been extinguished. Moreover, in different places they have been preserved in different forms and in different modes.

In the future, the task of respected musical figures (music connoisseurs) is to more persistently search for such songs, study them, detail their sound composition (tavysh), melodies (аһəң), and, based on all this, create an integral picture. If all these components (kisək) are taken into account, it will be possible to correctly and effectively direct the specific creativity of individuals (shəches) following this path. In this case, musical works, created in this way, cannot be perceived as an act of separation from the people. Once the works are based on their own people's property, their form alone will not be able to completely (forever) alienate these works from the people.

In this area, there are several examples of how easily such works are assimilated by the people. Several songs and individual kyuis from "TahirZuru" and "Buz eget" by Sultan Gabyashi were shortly accepted by the people as their "own" music. The fact that these works of Gabyashi, not purely Tatar, more precisely, including the motifs ("моң") of the Turks, Kirghiz and Crimean Tatars, which are close to the Tatars' heart, proves that different kyuis, composed of purely Tatar motifs ("моң"), will be accepted by the people with particular ease.

Isanbet believed that the creation of Tatar professional music would be hindered by some traditions of the musical past and the lack of development in the area of a new musical language.

\section{Conclusions}

Interestingly, from the post-war period, the same issues about the present and future of Tatar music were raised during numerous discussions, organized by the Union of Composers of the Republic and on its monthly creative "Thursdays". Moreover, by this time a large group of Tatar composers had grown up and significant successes had already been achieved in the development of many genres, which meant that during those disputes there were enough grounds to start discussions from, besides folk music. However, Isanbet and professional musicians focused on various musical phenomena, not to mention the 
fact that the interests of the Tatar people, the "simple" audience, were gradually pushed into the background, and the trend towards "academic" music for professionals grew stronger. Besides, the originality of Tatar music was interpreted in different ways.

\section{References}

Afisha Simfonicheskogo kontserta vostochnoi muzyki simfonicheskogo orkestra pod upravleniem A. Eikhenval'da ot 3 avgusta $1923 \mathrm{~g}$. [Playbill for the Symphony Concert of Oriental Music of the Symphony Orchestra Conducted by A. Eichenwald on August 3, 1923]. (In Russian)

Eikhenval'd, A. A. (1923). Narodnaia pesnia kazanskikh tatar ( $K$ segodniashnemu kontsertu $v$ Krasnoarmeiskom dvortse) [Folk Songs of the Kazan Tatars (For today's concert in the Red Army Palace)]. Izvestiia TatTSIKa. 26 avg. (In Russian)

Isənbət N. (1959) F. Kudasheva koncertlary [Concert by F. Kudasheva] // Sov. Tatarstany. - 1959. -20 maj.

K kontsertu dirizhera Eikhenval'da (1923) [On the Concert of the Conductor Eichenwald]. Izvestiia TatTSIKa. 1 iiulia. (In Russian)

Kozlov, I. V. (1928). Piatizvuchnye bespolutonovye gammy $v$ tatarskoi $i$ bashkirskoi narodnoi muzyke $i$ ikh muzykal'no-teoreticheskii analiz [Five-sound Non-semitone Scales in Tatar and Bashkir Folk Music and Their Musical Theoretical Analysis]. Izvestiia Obshchestva arkheologii, istorii i etnografii pri Kazanskom universitete. T. 34. Vyp. 1-2, pp. 160-178. (In Russian)

Moshkov, V. A. (2011). Melodii Volgo-Kam'ia [Melodies of the Volga-Kama Region]. (Pod. red. M. G. Kondrat'eva i N. Yu. Al'meevoi). 366 p. Cheboksary, Chuvash. kn. izd-vo. (In Russian)

Muzykal'naia, entsiklopediia v 6 t. (1978) [Musical Encyclopedia in 6 Volumes]. T. 4. 976 p. Moscow, Sovetskaia entsiklopediia. (In Russian)

Nikol'skii, N. V. (1920). Konspekt po istorii narodnostei Povolzh'ia [Synopsis on the History of the Volga Peoples]. 72 p. Kazan', Pervaia gos. tip. (In Russian)
Rybakov, S. G. (1897). Muzyka i pesni ural'skikh musul'man s ocherkom ikh byta [Music and Songs of the Ural Muslims with an Outline of Their Lives]. Zapiski Imperatorskoi Akademii nauk. 8 seriia. T. 2, No. 2, pp. 301-303. St. Petersburg. (In Russian)

Sh. G. (Sh. Usmanov?) (1923). Berenche tatar simfoniia kichose [The First Tatar Symphony Evening]. Tatarstan. 5 avgust. (In Tatar)

Simskii, M. (1928). Nad nami ne kaplet, pravda? [It can wait, can't it?]. Krasnaia Tatariia. 13 dek. (In Russian)

Simskii, M. (1923). Simfonicheskii kontsert Vostochnoi muzyki [Symphony Concert of Oriental Music]. Izvestiia TatTSIKa. 8 avg. (In Russian)

Simfonicheskii kontsert TatMuzo

[TatMuzo Symphony Concert]. Izvestiia TatTSIKa. 2 iiulia. (In Russian)

Tatarskii entsiklopedicheskii slovar' (1999) [Tatar Encyclopedic Dictionary]. 703 p. Kazan, Institut Tatarskoi entsiklopedii AN RT. (In Russian)

Tatar жcyrlaryn muzykaga saluga іаң̧a adym Tatarstan (1923) [A New Step in Putting Tatar Songs to Music]. 1 avg. (No. 144). Tatarstan. 1922. 21 noiab. (No. 254) (In Tatar)

U-v, A. (1923). Vecher vostochnoi muzyki $i$ iskusstva [Evening of Oriental Music and Art]. Izvestiia TatTSIKa. 2 avg. (In Russian)

V. G-n (1923). K kontsertu vostochnoy muzyki [On the Concert of Oriental Music]. Izvestiia TatTSIKa. 3 avgust. (In Russian)

Zakir, Z. (1923). Tatar muzykasyn eshlau yulynda [On the Ways to the Tatar Music Development]. Tatarstan. No. 151, 10 avgust. (In Tatar)

Zenz, V. (1926). Vostochnaia narodnaia muzyka: beseda s kompozitorom-etnografom A. A. Eikhenval'dom [Oriental Folk Music: A Conversation with the Composer-Ethnographer A. A. Eichenwald]. Dni. 27 iiunia. (In Russian)

Zvuki vremeni: (Muz. kul'tura Tatarstana) (1991) [The Sounds of Time: (Mus. Culture of Tatarstan)]. G. K. Vaida-Saidasheva; Kazan. nauch. tsentr, AN SSSR, In-t iaz., lit. i istorii im. G. Ibragimova. 124 p. Kazan', Tatar. kn. izd-vo. (In Russian) 


\title{
СТАТЬЯ НАКИ ИСАНБЕТА «НА ПУТЯХ СТАНОВЛЕНИЯ ТАТАРСКОЙ МУЗЫКИ» (1923) КАК ИСТОЧНИК НАУЧНОГО КОММЕНТИРОВАНИЯ ${ }^{1}$
}

Юлдуз Накиевна Исанбет, mileuscha@mail.ru.

\begin{abstract}
В статье представлен текстологический научный комментарий работы Наки Исанбета «На путях становления татарской музыки», опубликованной в Казани в 1923 г. под псевдонимом. Это была дань памяти старшему брату, пропавшему без вести в годы Гражданской войны. В работе убедительно доказано, что статья Наки Исанбета не потеряла своей актуальности и в наши дни. Ученый сумел грамотно обозначить ключевые тенденции в изучении татарской народной музыки и наметил пути развития профессиональной татарской музыки.
\end{abstract}

Ключевые слова: татарская музыка, татарская народная песня, Наки Исанбет, А. А. Эйхенвальд, С. Габяши, С. Сайдашев.

\section{Введение}

Народные мелодии казанских татар, записанные и обработанные Антоном Александровичем Эйхенвальдом для симфонического оркестра, впервые прозвучали 3 августа 1923 года на концерте восточной музыки, устроенном в Красноармейском дворце (ныне театр имени К. Тинчурина). В программу концерта вошли татарские песни «Каз канаты» («Гусиное крыло»), «Окоп көе» («Окопная песня»), «Салкын чишмә» («Студеный ключ»), «Мөслимә» («Муслима»), «Туган ил» («Родина»), «Газизә балдыз» («Своячница Газиза»). Это был первый в истории татарской музыки симфонический концерт восточной музыки. В нем приняли участие исполнители татарских народных песен Сара Садыкова, Хакима Чамаева и Ярулла Чамаев (Рис.1).

Среди газетных откликов [К концерту дирижера Эйхенвальда], [Симфонический концерт ТатМузо], [Татар жырларын музыкага салуга яңа адым], [В. Г-н], [Зен3], [Симский 1923], [Симский 1928], [Ш.Г.], [У-в], [Эйхеньвальд] на симфонический концерт татарской музыки особняком стоит статья Н. Исанбета «На путях становления татарской музыки» («Татар музыкасын эшләу юлында»), опубликованная, как это характерно для всех его публицистических материалов 1920-х годов, под псевдонимом 3. Закир ${ }^{2}$ [Закир] (см. подр. Приложение). Молодой поэт Н. Исанбет посетил

\footnotetext{
${ }^{1}$ По причине ухода из жизни автора структура статьи была выстроена в соответствии с требованиями журнала редактором Хабутдиновой М. М.

2 В основе псевдонима фамилия и имя старшего брата Н. Исанбета Заки Закирова, погибшего в годы Гражданской войны.
}

Казань по дороге на учебу в Харьковский университет. К этому времени основные темы и направления его творчества уже определились. В круг его интересов с ранних лет входило и татарское народное творчество. Посещение концерта А. А. Эйхенвальда и новые личные впечатления дали ему дополнительный материал для раздумий о судьбе татарской музыки в прошлом и будущем.

\section{Материалы и методы исследования}

В приложении статья Н. Исанбета публикуется на языке оригинала, так как мы столкнулись с объективными трудностями при переводе ее с татарского на русский язык. Некоторые шероховатости текста объясняются тем, что данный материал был опубликован без согласования с автором и без его редакторской правки, так как статья была подготовлена к печати после отъезда поэта из Казани. Кроме того, Н. Исанбет в своей работе прибегает к терминам, не имеющим аналогов в русском языке. При цитировании Н. Исанбета мы были вынуждены прибегать к условному переложению или упрощенному дословному переводу. В отдельных случаях в скобках приводятся варианты значений переводимых слов, чтобы облегчить понимание статьи. Некоторые термины всегда переводятся одинаково: «жыр» - «песня» (и только один раз, по контексту, как «народная вокальная музыка»), «көй»- как «көй», «музыканы эшләү» - как «становление музыки; сочинение музыки; музыкальное творчество», «мәдәниләштеру» - как «профессионализация; создание профессиональной музыки». Слово «моң» употребляется Н. Исанбетом в двух значениях: 1) «напев», но не любой, а обладающий 
тем качеством, которое определяется татарским словом «моң» (то есть в данном случае под «моң» подразумевается «озын көй», а под «напевом», соответственно, «протяжная песня» или «узун кюй»); 2) определение конкретного эмоционально-психологического состояния. В последнем случае из-за отсутствия русского эквивалента слово приводится на татарском языке (подробнее толкование слова «моң» будет рассмотрено далее).

\section{Обсуждение}

Статья Н. Исанбета опубликована позже первых откликов на концерт. Без сомнения, то, о чем говорится в статье, не раз и не два обдумывалось автором. Несомненно и то, что в творчестве А. А. Эйхенвальда он нашел ответы на какие-то мучившие его вопросы, и ему потребовалось время для того, чтобы взглянуть на них под несколько другим углом зрения, чем ранее, и определеннее сформулировать свою точку зрения на перспективы развития татарской музыки.

С момента падения в 1552 году Казанского ханства татарский народ на протяжении четыpex с половиной веков фактически не имел никаких шансов даже на элементарное развитие своей духовной культуры. Лишь литература с трудом сохраняла какие-то позиции. Только после известного «Высочайшего Манифеста об усовершенствовании государственного порядка» от 17 октября 1905 года, даровавшего в России демократические права и свободы, в городах с татарским населением стали постепенно осваиваться некоторые формы концертнотеатральной жизни, характерные для европейской и русской культуры. Театральные труппы, небольшие музыкальные коллективы и отдельные исполнители стали претендовать на получение права гражданства и, пусть иногда и с большим трудом, добивались разрешения на публичные выступления. Любительское искусство вступало на стезю профессионализма.

Но если у нарождающегося татарского театра быстрыми темпами формировался собственный репертуар (в том числе и переводный), создаваемый татарскими драматургами, то музыка в этом отношении сильно отставала. Немногочисленные, по существу любительские, произведения татарских авторов были наперечет, поэтому основу музыкального репертуара исполнителей-татар составляла народная музыка - в чистом виде и в несложных переложениях для пения с сопровождением или для от- дельных инструментов и ансамблей. Но даже элементарная обработка народных напевов оказалась делом трудным и, как показала жизнь, не только на первоначальном этапе становления профессиональной музыки.

У татар не было своих композиторов, получивших необходимое профессиональное образование. Их еще предстояло выучить, проведя через все долгие этапы музыкального воспитания от начального к высшему. Однако одно образование, к тому же и ускоренное, еще не гарантировало создания музыки, которая могла быть воспринята именно как национально татарская. А что нужно сделать, чтобы получалось именно так, никто четко не представлял. Оставалось только как-то ориентироваться на традиции народной музыки, на тот момент тоже еще не изученные. Для музыкантов - татар того времени, выросших на народной музыке и воспринимающих ее не разумом, а душой, научные знания о ней были не всегда обязательны. Но они были необходимы для пытавшихся работать в области татарской музыки композиторов других национальностей и будущих воспитателей как татарских композиторов, так и исполнителей, особенно певцов. На осознание специфических особенностей татарской музыки им требовались и время, которым они не всегда располагали, и определенные усилия. Кто-то из авторов новых произведений исходил из известных традиций, кто-то предпочитал их игнорировать, не замечать. Каждый действовал в меру своего таланта, знаний и ответственности и с разным результатом.

Одноголосные народные напевы или близкие к ним по духу новые авторские мелодии с трудом поддавались гармонизации, с которой связывалось введение в татарскую музыку многоголосия, неизбежного при стремлении к ее европеизации. Без многоголосия нельзя было ожидать освоения ни оперы, ни балета, ни других европейских академических жанров, о чем мечтали деятели татарской культуры. С точки зрения Н. Исанбета, ближе всего к адекватной многоголосной обработке татарских напевов подошел А. А. Эйхенвальд.

Статья состоит из двух разделов. Первый из них посвящен вопросам, связанным непосредственно с творчеством А. А. Эйхенвальда, второй - национальному своеобразию татарской музыки и некоторым вопросам дальнейшего развития татарской профессиональной музыки.

Начав статью с предположения, что «недавний татарский симфонический вечер, прове- 
денный под управлением маститого композитора А. А. Эйхенвальда, породил в головах многих любителей музыки новые мысли о татарской музыке вообще и ее будущем в частности», и заметив в завершение статьи, что пришла пора серьезно обсудить вопросы развития татарской музыки и что «особенно хочется услышать собственное мнение музыкальных деятелей, привыкших держать свое творчество в стороне от газетно-журнальных страниц», Н. Исанбет тем не менее, видимо, не надеется на широкое обсуждение поднятых им вопросов. Сопоставляя разные точки зрения, он делает это сам.

Приведенные им как положительные, так и негативные мнения о современном состоянии и будущем татарской музыки были не общепринятыми или высказанными кем-то публично, а сформулированы самим автором как возможные. При этом Н. Исанбет не спорит со своими возможными оппонентами, относящимися к татарской музыке критически (недаром к заглавию статьи дано примечание «Вместо прений», a не, например, «В порядке дискуссии»), и не отвергает их точку зрения только как антагонистическую, враждебную, а обычно анализирует, чем она обусловлена. Для ее возникновения, считает Н. Исанбет, в ряде случаев имеются реальные основания.

Автор статьи выражает уверенность в исторической неизбежности появления в недалеком будущем у татар профессиональной музыки, хотя и констатирует, что «до настоящего времени прогнозы о будущем татарской музыки были крайне пессимистическими». Будущий прогресс татарской музыки Н. Исанбет связывает с прогрессом татарской культуры в целом.

Он пишет, что в противовес пессимистическим прогнозам «должна была крепнуть вера в то, что так, как по мере экономического и политического роста независимых народов растут и развиваются их языки, литература, театр и музыка, музыка татарского народа, обладающего постепенно созревающими другими ветвями культуры, тоже когда-нибудь подрастет и достигнет совершеннолетия. Потому что если музыка является частью искусства, то само искусство является ветвью культуры, которая может расти и развиваться, только если будут здоровы все ее отдельные составляющие. Как и другие отрасли татарской культуры, ее искусство вынуждено идти вперед, не иначе как будучи навитым на общую историческую ось (не иначе как в общей исторической упряжке)», и, таким образом, Н. Исанбет указывает два первых шага, уже сделанных в этом направлении в музыке [Закир].

Первым шагом он считает собирание и нотную запись народных кюев, разбросанных по разным местностям (в личной библиотеке самого Н. Исанбета имелись известные татарской интеллигенции того времени нотные издания записей С. Рыбакова, М. Султанова, М. Берг и публикации послереволюционных литературно-музыкальных и молодежных обществ Казани, Оренбурга, Уфы). Вторым шагом, с его точки зрения, является творчество авторитетного музыканта Султана Габаши, который являлся автором а) новых музыкальных произведений, частично сотканных из татарских мотивов, б) кюев для ряда сценических произведений, в) переложений народных песен для хорового пения, сделанных на основе исследования звукового состава, размера и метрики.

Н. Исанбет считает, что в этом направлении движется и молодой музыкант Салих Сайдашев, как бы предвосхищая последующие события, так как Сайдашев, с осени 1922 года работавший в татарском театре, пока еще собственной музыки не писал и при оформлении спектаклей без особых ухищрений использовал народные мелодии.

Вместе с тем Н. Исанбет не преувеличивает заслуг своих современников и признает, что «все эти шаги на пути профессионализации татарской музыки были недостаточными, половинчатыми шагами. Хотя в их основе и чувствовалось стремление вместить татарскую музыку в научные, творческие формы соответственно общим для других народов музыкальным канонам, резко бросались в глаза неубедительность этих шагов и беспомощность приемов. Возможно, это шло от того, что наши специалисты не были в достаточной степени вооружены теоретическими, научными знаниями» [Закир]. Поскольку Н. Исанбет явно говорит не только рассмотренных им «двух шагах», а обо «всех этих шагах» («ләкин бу адымнарның, hәммәсе да», а не «ләкин бу адьммнар» или «ләкин бу ике адылм да»), здесь, видимо, дается обобщенная объективная оценка всех предыдущих собирательских и композиторских опытов в области татарской музыки в целом.

В дооктябрьский период собиранием, обработкой и публикацией татарской народной музыки, кроме единичного случая с М. Султановым, занимались не татары, а музыканты других национальностей, что Н. Исанбет считал 
исторически оправданным, хотя эти записи и обработки не всегда соответствовали народным оригиналам. Не вызывала у него сомнений и правомочность работы в области татарской музыки композиторов, не являющихся татарами. «Поскольку музыкальные культуры разных народов, как и специфические отрасли культуры, не отделяются друг от друга прочными барьерами и между ними существует множество общих связей, при вступлении музыки каждого культурного народа в полосу интенсивного развития случаи ее развития только собственными силами в истории не наблюдаются. Поэтому если в становлении французской музыки могли, развернувшись, работать признанные деятели итальянской музыки, то и немецкие композиторы могли настолько же без затруднений осваивать русскую музыку и приносить ей драгоценную пользу. Без сомнения, не можем вне этого канона (правила, обычая) отсидеться в стороне единственно мы. Не встретят такое с удивлением и у нас» [Закир], - считал он (впрочем, насчет последнего слегка заблуждаясь).

В наше время татарская музыка живет сама по себе и стоит вне поля зрения татарской интеллигенции. Но с начала 1920-х годов в течение примерно полувека во времена, когда общественность была живо заинтересована во внедрении в татарскую музыку серьезных жанров и в адекватном исполнении произведений татарской музыки, особенно тех, в которых в качестве тематического материала использовалась народная песня (этот прием был характерен как для творчества композиторов-татар, так и для пытающихся сочинять татарскую музыку русских композиторов) певцами и инструменталистами, получившими профессиональное (особенно консерваторское) образование, национальная неопределенность или даже полная чуждость многих произведений и манеры исполнения национальному восприятию татарской аудитории обычно объяснялись тем, что евреи и русские портят татарскую музыку, потому что не понимают ее. Н. Исанбета тоже многое коробило, во многом не нравилась ему кадровая политика Н. Г. Жиганова, который был и ректором консерватории, и председателем Союза композиторов, то есть единоличным властелином в сфере «серьезной» музыки республики, но степень национальной адекватности, «татарскости» музыки или исполнения $\mathrm{H}$. Исанбет никогда не измерял только национальной принадлежностью музыкантов.
Как видно из некоторых уже процитированных высказываний Н. Исанбета, он был объективен и замечал достоинства и недостатки не только татарских и нетатарских композиторов, но и даже самой татарской народной музыки. В статье приведены два противоположных по результатам примера работы с татарскими напевами представителей русской культуры, происходившей буквально на глазах (памяти) читателей.

Первый из них связан с деятельностью композитора и собирателя народной песни Я. В. Прохорова. Имеются сведения, что после Октябрьской революции он вел большую работу и по собиранию песен народов Поволжья. В начале 1920 года Я. В. Прохоров приехал в Казань для работы в музыкально-этнографическом отделе Центральной (Высшей) восточной музыкальной школы. Судя по тому, что Н. Исанбет называет его «одним из самых хорошо знакомых с восточной музыкой казанских профессоров», композитор уехал из Казани не ранее получения профессорского звания (если оно у него действительно было), то есть после того, как в мае 1921 года школа была преобразована в Восточную консерваторию. В том же 1921 году началась его работа в московском Государственном институте музыкальной науки (ГИМН) [Музыкальная энциклопедия, стб. 474], куда был приглашен и А. А. Эйхенвальд.

По заданию ли ГИМНа или по предложению наркомпроса ТАССР, но в 1922 году Я. В. Прохоров побывал в экспедиции по сбору татарского музыкального фольклора. Как анонсировала газета «Татарстан», на 3 ноября 1922 года научным центром Татнаркомпроса было запланировано «собрание работников восточного искусства для прослушивания новых записей татарских народных песен», в том числе 16-и песен в записи. Я. В. Прохорова [Татарстан. 1922], [Мошков]. Шесть татарских народных песен в его гармонизации были изданы Центральной восточной музыкальной школой еще в 1920 году. Я. В. Прохоров был известен казанцам и по его публичным выступлениям в качестве музыкального этнографа.

Оценивая результаты его деятельности, Н. Исанбет отмечает, что в последние годы В. Я. Прохоров предпринял немало попыток потрудиться на поприще татарской музыки, однако в результате пришлось убедиться, что татарский «моң» оказал сильное сопротивление тому, чтобы склонить перед ним голову. 
Н. Исанбет объясняет неудачу В. Я. Прохорова не тем, что тот, не будучи татарином, в принципе не способен постичь чужую музыку, а по-другому. Он считает, что, с одной стороны, неудаче способствовали недостатки самой татарской музыки, ее незрелость, невозделанность, пребывание в состоянии, трудно доступном для понимания других народов, а с другой - формальное отношение композитора к делу, его поверхностность. «Вместо того чтобы в процессе обработки татарской песни обратить внимание на ее природные специфические свойства, этот профессор придал большее значение надеваемой на нее условной одежде европейской музыки и общей музыкальной технологии (технике). В обработанных им кюях основной колорит татарских напевов сильно искажается, а используемые всеобщие технические средства находятся с прекрасными напевами в далеких отношениях», - считает Н. Исанбет [Закир].

А вот опыт Эйхенвальда он находит удачным, оценивает его как победу: «Хотя сам Эйхенвальд иной национальности, но, если исходить из его работ, он правильно понял своеобразие использованных им татарских песен и их основной характер. Татарский „моң“ воспроизведен в его песнях с очень незначительными погрешностями. В придачу к этому, когда он, используя основной напев в качестве фундаментальной основы, расцвечивает (упестряет) его по правилам теории музыки, основная нить (линия) не прерывается, а многочисленные узоры не теряют связи с основной материей (тканью). Короче, взаимосвязь между бесчисленными линиями (нитями, струнами; кыллар), голосами, ступенями напева не нарушается. В результате же такие песни, как «Салкын чишмә» и «Туган ил», в природном состоянии настолько однообразные и утомительные, что это не может не обратить на себя внимания, в приодетом, прихорошенном и подкрашенном виде становятся привлекательными и под потрясающие дух звуки составленного из невесть скольких инструментов симфонического оркестра, чисто по-татарски слаженно звуча, представляют единое целое» [Закир].

А. А. Эйхенвальд придавал большое значение тому, как будут восприняты его записи и обработки самими народными исполнителями, и стремился добиться их одобрения, то есть при обработках народных напевов исходил не из голых учебных правил гармонизации, а из стремления к достижению естественности зву- чания для уха национального слушателя. Напомню описание процесса работы с народным материалом, данное им корреспонденту парижской газеты «Дни» в 1926 году: «Трудна очень оказалась обработка, гармонизация записанного. Сначала обрабатывал по всем правилам контрапункта и европейской гармонизации, затем приглашал знатоков песни этой национальности и воспроизводил перед ними эти песни на рояле. И по большей части слышал один и тот же убийственный приговор: „не наш музыка!““ ... Некоторые вещи приходилось переделывать по 30-40 раз - пока, наконец, перестанут говорить - „не наш музыка!“ Всю работу приходилось ставить чисто опытным путем. В конце концов, как будто уловил характерность их гармонии...» [Эйхенвальд]. Наверное, это был единственно правильный, но требующий большого упорства и времени путь освоения чужой поначалу культуры.

Н. Исанбет высоко оценил результат обращения А. А. Эйхенвальда к татарской народной музыке. Он отметил: «Правда, и в его музыке не без шероховатостей (корявостей), и у него еще обилие чисто технических приемов, в некоторых местах возникают затруднения с правильной передачей естественного звучания. Но, во-первых, ведь можно сказать, что пока еще это первый опыт обработки татарских напевов подобным способом, во-вторых, в какой-то мере должно быть принято во внимание и то, что композитор принадлежит к иной национальности, в-третьих, в исполняющем песню мощном оркестре нет ни одного татарина, чувствующего и воспринимающего эти напевы душой. Но ясно одно: этот опыт наглядно показал, что и татарская музыка способна безгранично прогрессировать, что ее можно облечь в форму, которая не принесет позора на международном музыкальном майдане (арене), на майдане западной музыки, обладающей высоким профессиональным уровнем, что для этого необходимы только преданные своему делу специалисты, любящие музыку деятели, школы, организации» [Закир].

Н. Исанбет находит необходимым дальнейшее продолжение работы в направлении, заданном А. А. Эйхенвальдом, и расширение выбранной им дороги.

Появление одного подготовленного композитора не приведет к решению всех проблем. В любом искусстве, особенно в таком, как без движения лежащая на месте “сырая” (незрелая) татарская музыка, один единственный человек 
может отвечать только за очень малое, считает Н. Исанбет. С его точки зрения, для того чтобы в дальнейшем работа была более результативной, особенно важно, чтобы за дело взялись национальные музыканты, а труды Эйхенвальда могли бы послужить для них ориентиром. «Таким нашим специалистам, как Габаши и Сайдаш, до настоящего времени старательно искавшим пути развития татарской музыки и вложившим в свои искания много труда, работы Эйхенвальда должны облегчить поиски. Если они, договорившись, смогут работать на этом пути совместно, это станет особенно добрым предзнаменованием и обеспечит достижение еще более плодотворных результатов» [Закир]. Н. Исанбет надеется на сплочение татарских музыкантов и на расширение поля их деятельности.

Посвящая второй раздел статьи перспективам развития татарской музыки в новых условиях послеоктябрьской жизни, Н. Исанбет рассматривает их в тесной связи с жизнью народа, его потребностями и традициями его музыкального творчества. Разговор о профессионализации татарской музыки Н. Исанбет находит нужным предварить вопросами:

1) для кого должна предназначаться эта музыка?

2) какой она должна быть?

И без всяких, как он оговаривает, «предварительных уловок» заявляет: 1) для народа (массы) и 2) в корне новой (революционной). Последовательно и убежденно, демократичный в собственном творчестве, Н. Исанбет призывает к созданию музыки, понятной и доступной народу. По его мнению, в этой музыке следует избегать лишних ухищрений, засилия музыкальной технологии, слепого следования всем установкам и правилам теории музыки: «В области музыкального творчества, как и во всех других отраслях искусства, мы в принципе на стороне творчества, близкого самому народу. Если театр, живопись, поэзия, скульптура, взятые из жизни, из среды самого народа, должны развиваться, оставаясь близкими ему, музыка тоже не может не войти в переплетения (сетку, рамки) этого же самого канона.

Исходя из этого, мы призываем: пусть при дальнейшей работе на музыкальном фронте и приведении татарских песен в систему взаимосвязь народа и музыки не разрывается, как это характерно для западной музыки, очень далекой от народа и порожденной только фантазиями индивидуумов или выстроенной, подобно конструкции, с помощью схематических установок голой теории музыки, а при әсасән (әсасән - нигез буларак эшләгәндэ, төптә $=$ в основе, в принципе) сочинении песен и музыки для народа пусть доля в музыке технических приемов будет на положении дополнительного (вспомогательного) приложения, вроде росписи (украшения)...

Как было сказано выше, есть угроза, что, если мы будем откровенно выдвигать на первый план эту самую теорию, татарская музыка будет всегда пребывать дальше дальнего (в далекой дали), без собственной участи (своей доли) в жизни, без надежды на будущее» [Закир].

Демократичность в музыке Н. Исанбет считает важной, в частности, и потому, что относит музыку к самым сильным средствам воспитания человека: «Сколько бы духовной пищи не смог получить человек от какой- нибудь содержательной научной дискуссии, но после хорошего исполнения хорошо сделанного произведения он уйдет с еще более полным впечатлением. Особенно большое значение имеют формирование чувств человека, воспитание его духовных сил (мощи). В нашей построенной на новой основе жизни воспитанию народа (массы) в этом отношении будет уделено специальное внимание» [Закир].

Подчеркивая значение этого вопроса для современной татарской действительности, Н. Исанбет останавливается на двух важных с точки зрения воспитания молодого поколения вопросах, один из которых связан с прошлыми традициями татарской музыки, другой - c ee будущими новыми направлениями, оба - с мировосприятием народа. В таком ракурсе, как это сделал Н. Исанбет, эти вопросы не рассматривались ни до, ни после него.

Музыкальный язык татарской музыки начала XX века был языком народной песни. В каком направлении будет развиваться творчество татарских композиторов, должны ли они опираться на привычные народнопесенные традиции или создавать свою музыку вне их, как ввести многоголосие западноевропейского или русского образца в одноголосный народный напев - все это следовало устанавливать опытным путем. Как показала творческая практика ближайшего времени, механическое использование молодыми татарскими композиторами чужого опыта отвергалось татарской слушательской аудиторией, которая в большинстве случаев не хотела принимать новые сочинения за татарскую музыку. Но и русским слушате- 
лям, в свою очередь, ни татарская народная музыка, ни сочинения татарских композиторов не были близки.

Непонимание, а в некоторых случаях отторжение татарской народной музыки слушателями других национальностей Н. Исанбет объясняет некоторыми специфическими, чисто национальными особенностями самой народной музыки, а также некоторыми условиями ее бытования. Но в понимании того, какие качества характеризируют ее в первую очередь, что определяет лицо татарской музыки, он расходится с точкой зрения музыкальных экспертов своего и ближайшего к нему времени.

После публикации в 1928 году в «Известиях Общества археологии, истории и этнографии при Казанском университете» статьи скрипача, композитора и исследователя татарской и башкирской народной музыки И. А. Козлова «Пятизвучные бесполутоновые гаммы в татарской и башкирской народной музыке и их музыкально-теоретический анализ» [Козлов] в казанских музыкальных кругах основной (главной, единственной) особенностью татарской народной музыки стала считаться ее опора на бесполутоновую (ангемитонную) пентатонику, или китайскую (шотландскую) гамму.

Не стоит думать, что до этой публикации о пентатонике в Казани вообще никто ничего не знал. Присутствие в татарских песнях «пятитонной гаммы» отмечено известным русским этнографом и собирателем народных, в том числе татарских, песен (Мошков) С. Г. Рыбаковым [Рыбаков]. Первоначальные сведения о пентатонике и, может быть, о посвященных ей трудах русских ученых второй половины XIX века должны были быть известны преподавателям и выпускникам Казанского музыкального училища. С открытием в Казани в конце 1919 года Центральной (с 1 ноября 1920 г. - Высшей) восточной музыкальной школы (с марта 1922 г. - Восточной консерватории) в ней под кураторством известных московских этнографов было сформировано музыкально-этнографическое отделение, а при последнем - музыкально-этнографическая ассоциация, члены которой вели большую собирательскую и просветительскую работу. Планируемую серию трудов отделения открыл изданный в 1920 году «Конспект по истории народной музыки у народностей Поволжья» П. В. Никольского [Никольский], в котором, в частности, затронуты вопросы о роли и значении пентатоники в музыкальном наследии поволжских народов. Есть сведения, что эта работа издавалась также в переводах на татарский и чувашский языки. Среди 11-и научных докладов, прочитанных на заседаниях ассоциации в 1921 году, были доклады И. А. Козлова «Народная музыка северных мусульман» и «Пятизвучные бесполутоновые гаммы в татарской и башкирской народной музыке и их музыкально-теоретический анализ», на основе которых и написана затем упомянутая статья [Вайда-Сайдашева].

После того, как А. А. Эйхенвальд во вступительном слове на своем концерте отметил, что «все татарские старинные песни имеют определенный музыкальный склад и построение на своеобразной пятинотной гамме (родственной китайской)», о существовании пентатоники узнала и самая обычная публика, притом татарская. Но все же деятели татарской музыки всерьез заговорили о пентатонике только после публикации статьи Козлова. Видимо, это было связано с тем, что наряду с констатацией пентатонности татарской народной музыки и общими сведениями о пентатонике Козлов приводил конкретные примеры пентатонных гамм, анализировал их интервальный состав и ладовые наклонения, рассматривал вопросы аккордообразования и постановки ключевых знаков (определения тональности), то есть, казалось бы, статья давала некое направление для практического использования пентатоники. Вместе с этим статья Козлова подсказывала новые пути для ученых манипуляций с пентатонными звукорядамии, их толкований, терминологических изысков. Словом, в связи с ней было о чем поговорить.

В ответах на вопросы журнала «Яналиф» «О татарской музыке» в 1931 г. первым из татарских музыкантов проблему пентатоники затронул С. Габаши [Габаши]. Практический и теоретический интерес к пентатонике особенно возрос после открытия в 1945 году Казанской консерватории, в которой начали планомерно готовить татарских композиторов. В пентатонике стали видеть не просто главную, но единственную достойную внимания особенность татарской музыки. Но если в свое время А. А. Эйхенвальд отмечал, что пентатоника не препятствовала татарской музыке быть образно богатой и интересной («Несмотря на кажущуюся, на первый взгляд, бедность этой пятинотной гаммы, песни казанских татар настолько разнообразны, что приходится изумляться: как это народное творчество достигло таких комбинаций со столь небольшим количеством звуков и 
создало глубокие по содержанию и настроению разнообразные мелодии, от самых грустных до залихватско-веселых» [Эйхенвальд]), то в 1950е годы к ней стали относиться, скорее, негативно. Пентатоника как пережиток прошлых эпох стала виноватой в том, что до Октябрьской революции у татар не было профессиональной музыки, что татарская народная музыка одноголосна, занудна и однообразна, что татарские мотивы в качестве тематической основы крупных форм не способны к развитию, и вообще культурным людям противопоказано слушать пентатонную татарскую музыку, потому что она невыносима. Пентатоника тормозит развитие татарской профессиональной музыки, поэтому ее следует изжить, преодолеть, искоренить, обогатить полутонами, заменить диатоникой, обогащенной хроматизмами, и лучше всего вообще отказаться от нее в пользу мажора-минора XIX века. А ведь подобные мысли высказывались не в начале 1920 -х годов, когда татарская профессиональная музыка находилась в зачаточном состоянии, а в середине века, когда татарская музыка могла гордиться своими достижениями не только в масштабе страны, но, если принимать во внимание хотя бы балет Ф. Яруллина «Шурале», то и на международном уровне.

Татарская народная музыка действительно пентатонна. Но ее национальное своеобразие заключено не в пентатонике, как таковой. Ангемитонная пентатоника, известная с древних времен и свойственная очень многим европейским и азиатским народам, вообще не имеет национальности. Музыка каждого из этих народов индивидуальна и легко отличима от пентатонной же музыки любого другого народа. Казанская публика и казанские музыкальные деятели, в свое время побывавшие на концертах [Казань] трех международных конференций композиторов «пентатонной зоны» (Татария, Башкирия, Чувашия, Бурятия, Якутия, Китай, Корея, Монголия и др.), могли убедиться в этом лично. Точно также нетрудно различить национальную принадлежность диатонических, мажороминорных или даже додекафонных произведений композиторов разных народов Европы (сопоставьте, например, музыку немцев, итальянцев и чехов и т. д.). Дело не в звуковых или ладовых системах, а в национальном характере, психологии, менталитете, эмоционально-психологическом состоянии народа на данном историческом отрезке времени и их отражении в музыке.
Чтобы татарский народ воспринял какойлибо напев как родной, одной пентатоники мало. Напев должен быть созвучен душе народа, иначе он останется к нему равнодушным или отвергнет его, вне зависимости от того, пентатонный он или нет. В отличие от профессиональных музыкантов народ не подозревает о существование каких-то звуковых систем, далек от сознательного «использования» каких-то известных приемов, он просто изливает в музыке свою душу, интуитивно находя необходимые музыкальные средства. Народная музыка рождается не по шаблону, а по вдохновению, и, хотя композиторская музыка иногда может быть сконструирована по известным правилам, описанным в учебниках, нельзя ждать подобного от народа.

Оценку «чужими нациями всех татарских песен как похожих друг на друга однообразных, жалобных, тоскливых звуковых сочетаний» и неверие не только представителей других наций, но и многих татар в будущее татарской музыки Н. Исанбет связывает не с ограниченными возможностями пентатоники, а с тем, что в периоды, предшествовавшие концерту А. А. Эйхенвальда, народная музыка доходила до слушателей «только в своем природном виде, таком, как она сохранилась в народе». Но в народе и так сохраняется далеко не все. «О том же, что многие песни, напевы, раздавленные колесами истории, пропали, а уцелевшая их часть погибла в условиях трагедии порабощения, наступившего после татарского инкираза (имеется в виду падение Казанского ханства. Ю. И.), нечего и говорить», - утверждает Н. Исанбет [Закир].

Какой была музыка Волжской Булгарии или Казанского ханства, остается только предполагать (однажды в личном разговоре Н. Исанбет упомянул об удивительно светлом солнечном напеве как сохранившемся с булгарских времен, который, несмотря на его оригинальность, обычно причисляется татарскими музыковедами к напевам совершенно иной классификационной группы). В последующие же века татарский народ «взял песню и музыку себе в спутники для того, чтобы через них сильнее изливать свои горестные жалобы на горькую судьбу, и мы должны относиться к этому с осторожностью и вниманием», - считает Н. Исанбет [Закир].

Поэт и фольклорист пишет: «Та часть татарской музыки, которая, обретя гражданство, хранилась в памяти народа, проникнута без- 
мерной безысходностью, скорбью, горьким плачем (неудовлетворенностью жизнью). Это своеобразие досталось нам в наследство от немилосердной (беспощадной, бессердечной) истории. Сначала существуя как жертва борьбы за трон собственных ханов, затем став горестной (жалкой) жертвой русского империализма, татарский народ на протяжении последних 3-4 столетий был вынужден утолять свою жажду только такими горькими напитками» [Закир].

Скорбными татарские напевы делала не пентатоника, а глубокая рана, веками жившая в душе народа. Пентатоника же вместе с особыми формами песенного и инструментального (скрипичного) распевов и присущим многим народным певцам характерным тембром голоса («со слезой», но без надрыва) как нельзя более способствовали раскрытию чувства неизбывной боли, с которым неразрывно связано понятие «моң».

В академической музыке понятия «моңу» в том смысле, как это слово употребляется в татарском языке, нет. Однако вряд ли татарская музыка в этом отношении абсолютно уникальна. Например, «моң» свойственен также протяжным песням башкир - ближайшего родственного татарам народа. Но, по сравнению с татарскими, песни башкир отличаются большей широтой и каким-то ощущением внутренней свободы. Н. Исанбет объяснял это тем, что башкиры жили на больших пространствах в окружении красивейшей уральской природы, что придавало им силы. Даже при поверхностном ознакомлении своеобразный «моң» ощутим в музыке американских негров (афроамериканцев) или, например, в тембре некоторых восточных инструментов (например, гавайской гитары). При специальном изучении этого вопроса «моң», наверняка, выявится в народной музыке и некоторых других народов, чье творчество пока еще малоизвестно.

Русские музыкальные деятели и русские слушатели той поры воспринимали татарские напевы, как монотонные и одинаковые во многом потому, что им было неведомо чувство татарского «моң» и тем более не ощущались ими его оттенки. Но, быстро утомляясь от непонятной по настроению музыки, они видели корень зла в пентатонике.

Может быть, в каких-то трудах о татарской музыке правильное употребление и правильное толкование слова «моң» и встречаются. Но поскольку эти труды пишутся на русском языке и обычно специалистами, плохо владеющими та- тарским языком, такая вероятность мала. Не интересуясь хотя бы тем, в каком значении употребляется это слово в татарском языке, многие из этих специалистов пытаются, не без долгих мучений, дать ему собственное умозрительное толкование, обычно исходя из характера музыки и тех музыкально-выразительных средств, которые, на их взгляд, этот «моң» и создают.

Например, Г. С. Сабирзянов уверяет читателей «Татарского энциклопедического словаря»: «Моң, термин, определяющий нац<ациональный> колорит татар $<$ ской> духовной культуры, специфическую черту мироощущения, эмоциональное состояние сдерживаемой печали, выражающиеся в варьировании оттенков осн $<$ овной $>$ интонации. М. особенно ярко проявляется в музыке, поэзии, живописи» [Татарский энциклопедический словарь, с. 365]. Такую дефиницию можно долго критиковать как набор слов. Но дело не в том, что такие разные явления, как «колорит» культуры, черта мироощущения и эмоциональное состояние не могут «выражаться в варьировании» чего-либо, и не в том, что автор, видимо, не отдавал себе отчета, о какой интонации идет речь - речевой или музыкальной (а что делать с безынтонационной живописью?), и даже не в том, что варьировать «оттенки» основной интонации (если речь идет о мелодическом обороте) невозможно. Главное же в том, что автор считает «моң» варьированием, то есть композиционным приемом. С попыткой истолковать «моң» как средство музыкального языка и формообразования приходилось встречаться в работах и других авторов.

На самом же деле «моң» - это чувство, точнее, одно из человеческих чувств, свойственных натуре татарского человека. На определенных этапах исторического развития это чувство становилось всепоглощающим, что накладывало свой отпечаток на все стороны жизни татарского народа, в том числе и на его литературу и искусство. В музыке с особой силой оно проявилось в татарских народных протяжных песнях - «узун кюй» (татар. «озын көй»). Наверное, поэтому казанские музыканты, в первую очередь музыковеды, подходя к протяжным песням абстрактно, вне культурно-исторического контекста, «моң» считают музыкальным термином.

Точному и полному переводу слова «моң» на русский язык мешают объективные предпосылки. При переводе татарских литературных текстов эквивалент разным значениям этого 
слова в контексте целого обычно находится. Но в том смысле, как оно употребляется по отношению к музыке, на русский язык (да, видимо, и на большинство языков других народов) слово «моң» непереводимо, потому что этим народам неведомо чувство, обозначенное этим словом. Объяснить его значение не только русским, но иногда и некоторым современным татарам бывает трудно, потому что человек не может просто на словах понять, что представляют собой, например, «гордость», «совесть», «любовь» или другие чувства, если он сам никогда их не ощущал. («Никакого „моң“а нет, а есть такая изюминка, которая украшает напев», - любил повторять профессор Казанской консерватории А. С. Леман.) Но все же чуткий, способный на сопереживание человек, не только общающийся с носителем этого чувства, но и вникающий в его жизненные обстоятельства, сумеет ощутить это чувство сердцем.

Понятия или термины, отсутствующие в каком-либо языке, обычно входят в него на языке заимствуемого слова, воспроизводимого в транскрипции. Два звука из трех, составляющих слово «моң», фонетически очень далеки от русского языка, и по правилам записи звуков татарского языка буквами русского алфавита (татарское «о» = русскому «у»; а татарское «Н» - русскому «нг») «моң» в транслитерации будет выглядеть как «мунг» (или, в крайнем случае, «мун»), что не совсем привычно и пока еще никем не применяется. Но здесь уже ничего не поделаешь. Из-за отсутствия эквивалента этого слова на русском языке при письме или речи на нем существует выбор только между транслитерацией «мунг» или употреблением слова «моң» на татарском языке. Вариант ТЭС («мон») является антинаучным.

Чувства человека общественно обусловлены и историчны, как и сама человеческая личность, изменяющаяся в ходе истории.

Интересные наблюдения о сущности моң содержатся в статье Н. Исанбета о творчестве Фариды Кудашевой (1959): «Жырны жырлаганда безнең халык жырчыдан көй белән бергә күңел тавышын, анда салынган хис байлыгын, ягъни көйнең эчке жанын, шуның хәрәкәтен, динамикасын да сорый. Моң дигән хикмәтле нәрсә ул шул жанга үтеп керү алымнары һәм традицияләре белән үрелгән булырга кирәк. Шулай булгач, моң дигәнне кайберәүләр кебек кайгы-сагыш мәгънәсендә аңларга ярамый. Ул монда ихтыяж мәгънәсендә килә. Ягъни, моң ул - халыкның күңел ихтыяжын үти» [Исәнбәт]. - «Когда наш народ поет песню, то требует от певца вместе с мелодией голос души, с заложенным в нем богатством чувств, то есть внутреннюю душу мелодии, в ее движении, динамике. Этот загадочный моң должен быть в переплетении приемов, пронизывающих душу, и традиций. Если так, то нельзя понимать под моң горесть-тоску, как считают некоторые. Он здесь используется в значении „потребности“. То есть, моң реализует душевные потребности народа» (подстр. пер. наш - M. X.).

Необходимо обратить внимание еще на одну особенность «моң» в музыке, мимо которой не прошел Н. Исанбет, отметивший, что протяжная песня была в период горестной колониальной жизни спутником народа. Народ не только изливал через нее свои «горестные жалобы на горькую судьбу», но и находил в ней утешение. Протяжные песни, особенно башкирские, очень красивы, в них очень сильно эстетическое начало. Именно «моң» и является самым характерным признаком бережно сохраненной народом протяжной песни, с которой в первую очередь ассоциируется понятие татарской народной музыкальной классики. Как «не татарская» народом воспринималась музыка, не просто использующая полутона, а лишенная того, что называют словом «моң».

\section{Результаты}

При всей любви к татарским протяжным песням и высокой оценке их роли в жизни народа в прошлом Исанбет не видит особой перспективы их бытования в будущем, потому что с Октябрьской революцией круто изменилась жизнь народа, изменились исторические условия его_существования. Именно поэтому, считает он, в будущем татарская музыка должна быть «революционной» («инкыйляби»), но не в том смысле, как «отражающая идеи конкретно Октябрьской революции», а в «корне измененной, новой». Употребление при переводе определения «новаторский» вместо «революционный» здесь было бы не вполне уместно, так как в татарском музыковедении за ним закрепилось несколько иное значение.

В статьях и исследованиях, посвященных новаторству в татарской музыке, речь обычно идет не о подлинном обновлении татарской музыки изнутри, а об использовании татарскими композиторами музыкально-выразительных средств, форм и жанров классической и современной музыки (иногда это превращалось в са- 
моцель), ранее в татарской музыке не использовавшихся. Эволюция татарской музыки рассматривается скорее с педагогических позиций как поэтапный процесс профессионального образования, приобретения знаний и совершенствования. Новатором в чем-то (употребление полутона или доминантсептаккорда, написание квартета или оперы, использование формы сонаты или трехголосной фуги и др.) называется тот, кто первым перенес на татарскую почву отдельные открытия дальних и ближних предшественников. Однако с таких позиций фактически вся музыка, написанная татарскими композиторамипрофессионалами (по крайней мере, до середины XX века), является для татарского искусства новаторской. Да и дальнейшее обновление татарской музыки в большей мере основывалось на заимствованных творческих идеях. То, что точки зрения развития татарской музыки называется новаторством, с точки зрения европейской музыки будет называться творческим развитием ее традиций. Таким ускоренным путем профессионализации шли композиторы всех союзных и автономных республик СССР, не имевших до революции профессиональной музыки европейского типа.

Но в языке, формах и жанрах татарской профессиональной музыки можно найти много действительно нового, оригинального и притом собственного, созданного именно татарскими композиторами, но остающегося вне поля зрения исследователей, не стремящихся выйти за привычные рамки учебно-педагогической проблематики. В частности, следует обратить внимание на эмоционально-образное обогащение татарской музыки, достигнутое иногда с помощью самых обычных музыкальных средств и приемов, в науке давно переговоренных. Автору этих строк приходилось отмечать, что жизнерадостность и оптимизм ввел в татарскую музыку С. Сайдашев, взволнованность - Р. Яхин (на эту особенность музыки Яхина обратил мое внимание Н. Жиганов), но в целом проблема остается неизученной.

Говоря о необходимости коренного изменения татарской музыки, Н. Исанбет имеет в виду как раз ее содержательную сторону. Его беспокоит, что «дети народа, подрастающие на свободном просторе новой свободной жизни как единственные хозяева всех ее источников», вступают в новую жизнь, имея в своем наследии только музыку колониального времени. Ее своеобразие не позволяет ей «быть в согласии и единстве с новыми условиями свободной жиз- ни», отмечает он. Современному поколению необходимы кипучая жизнь (хәят), свобода, раскованность (ирек), удаль (житезлек), радость (шатлык), праздничность (бәйрәм), внешнее проявление чувств, выплескивание эмоций, торжество (нәмәеш) (нәмаеш / нөмаиш)

А наша музыка не может воплотить этого. Поэтому деятели, работающие над татарской музыкой, должны в будущем со вниманием отнестись к этой особенности реального положения дел.

Среди татарских песен вне этого основного своеобразия стоят (находятся) только немногочисленные такмаки и баиты. Насколько было реально, что такмаки и баиты, существовавшие в прежние времена во множестве, по историческим причинам выпав из жизни, забывались и их следы постепенно терялись, настолько далека возможность, что их удастся отыскать.

Поэтому в будущем нам придется этот вид музыки создать самим.

По этому пути тоже не придется идти не по следу (по целине). Потому что, как бы их ни было мало, нельзя сказать, что у нас совсем нет песен и напевов, в которых не погасла искра жизни. Тем более что в разных местах они сохранялись в разных формах и на разный лад.

В будущем задача уважаемых музыкальных деятелей (знатоков музыки) заключается в более упорных поисках таких песен, их исследовании, детализации их голосов (тавыш), мелодий (ahəң) и в создании на основе всего этого цельной картины (образа). Если все эти составляющие (кисәк) будут учтены, станет возможным направить на верный и результативный путь конкретное творчество отдельных личностей (шәхес). В таком случае создание музыкальных произведений подобным образом нельзя будет воспринимать и как отрыв от народа. Потому что раз в основу произведений положено собственное народное добро, только их форма не сможет окончательно (совсем) отдалить произведения от народа.

В данной области имеется несколько примеров легкого усвоения таких произведений народом. Несколько песен и отдельных кюев из «Таһир - Зөһрә» и «Бүз егет» Султана Габаши за очень короткое время вошли в народ как его «собственная» музыка. То, что в этих произведениях Габаши основной материал не чисто татарский, точнее, с участием близких татарам мотивов («моң»ов) турок, киргизов и крымских татар, является доказательством того, что разные кюи, составленные из чисто татарских мо- 
тивов («моң»ов) войдут в народ с особенной легкостью.

Н. Исанбет считает, что созданию татарской профессиональной музыки будут препятствовать некоторые традиции музыкального прошлого и невыработанность нового музыкального языка.

\section{Выводы}

Интересно, что начиная с послевоенного времени об этом же самом, казалось бы, говорилось во время многочисленных дискуссий о настоящем и будущем татарской музыки, организуемых Союзом композиторов республики, и на его ежемесячных творческих «четвергах». Причем к этому времени выросла большая группа татарских композиторов, а в развитии многих жанров уже были достигнуты значительные успехи, то есть при спорах было из чего исходить и кроме народной музыки. Однако внимание Н. Исанбета и музыкантовпрофессионалов было сосредоточено на разных явлениях, не говоря уже о том, что интересы татарского народа, «простой» аудитории постепенно оттеснялись на второй план, крепла ориентация на «ученую» музыку для специалистов. По-разному понималось и своеобразие татарской музыки.

\section{Литература}

Афиша Симфонического концерта восточной музыки симфонического оркестра под управлением А. Эйхенвальда от 3 августа 1923 г.

B. Г-н К концерту восточной музыки // Известия ТатЦИКа. 1923. 3 авг.

Закир 3. Татар музыкасын эшләу юлында // Татарстан. 1923. № 151. 10 авг.

Звуки времени: [Муз. культура Татарстана] / Г. К. Вайда-Сайдашева; Казан. науч. центр, АН СССР, Ин-т яз., лит. и истории им. Г. Ибрагимова. Казань: Татар. кн. изд-во, 1991. 124 с.

Зенз $B$. Восточная народная музыка: беседа с композитором-этнографом А. А. Эйхенвальдом // Дни. 1926. 27 июня.

Исәнбәт Н. Ф. Кудашева концертлары // Сов. Татарстаны. - 1959. - 20 май.

К концерту дирижера Эйхенвальда // Известия ТатЦИКа. 1923. 1 июля.

Козлов И. В. Пятизвучные бесполутоновые гаммы в татарской и башкирской народной музыке и их музыкально-теоретический анализ // Известия Общества археологии, истории и этнографии при Казанском университете. 1928. Т. 34. Вып. 1-2. С. 160178.

Мошков В. А. Мелодии Волго-Камья (под. ред. М. Г. Кондратьева и Н. Ю. Альмеевой). Чебоксары: Чуваш. кн. изд-во, 2011. 366 с.
Музыкальная энциклопедия в 6 т. Т. 4. М.: Советская энциклопедия, 1978. 976 с.

Никольский Н. В. Конспект по истории народностей Поволжья. Казань: Первая гос. тип., 1920. 72 с.

Рыбаков С. Г. Музыка и песни уральских мусульман с очерком их быта // Записки Императорской Академии наук. 8 серия. Т. 2, № 2. СПб., 1897. C. 301-303.

Симский М. Над нами не каплет, правда? // Красная Татария. 1928. 13 дек.

Симский М. Симфонический концерт Восточной музыки // Известия ТатЦИКа. 1923. 8 авг.

Симфонический концерт ТатМузо // Известия ТатЦИКа. 1923. 2 июля.

Татарский энциклопедический словарь. Казань: Институт Татарской энциклопедии АН РТ, 1999. $703 \mathrm{c}$.

Татар жырларын музыкага салуга яңа адым // Татарстан. 1923. 1 авг. (№ 144).

Татарстан. 1922. 21 нояб. (№ 254)

У-в А. Вечер восточной музыки и искусства // Известия ТатЦИКа. 1923. 2 авг.

Ш. Г. (Ш. Усманов?) Беренче татар симфония кичәсе // Татарстан. 1923. 5 авг.

Эйхенвальд A. A. Народная песня казанских татар (К сегодняшнему концерту в Красноармейском дворце) // Известия ТатЦИКа. 1923. 26 авг.

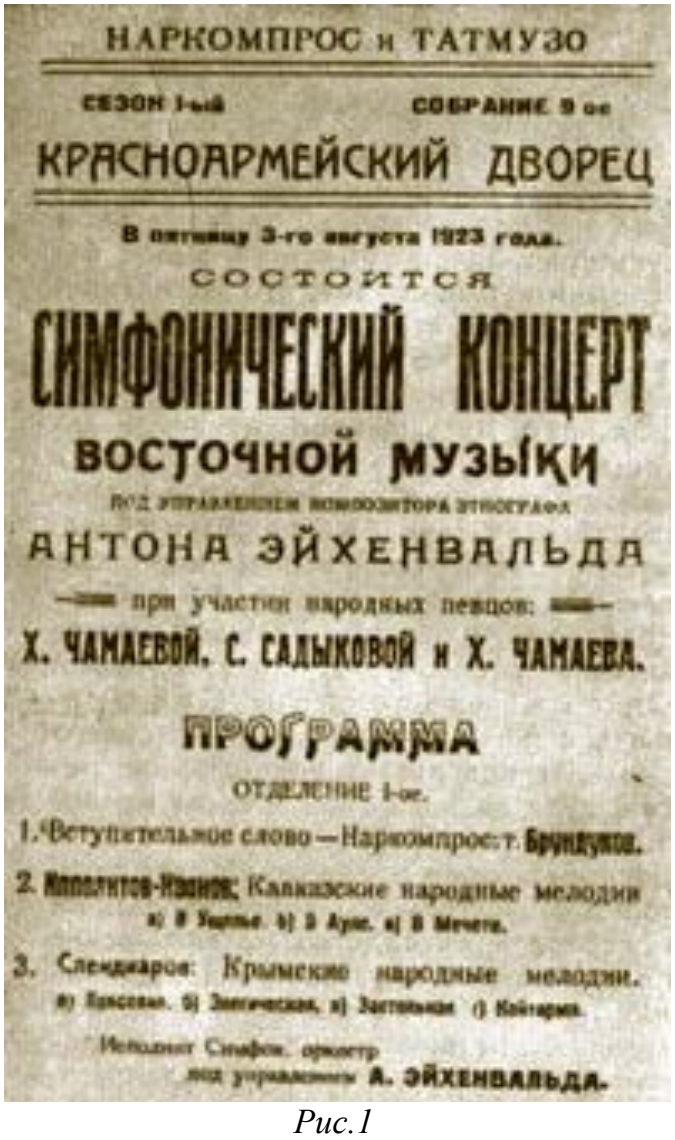

Puc. 1 
Приложение

Закир 3. Татар музыкасын эшләү юлында / Мөнакашә ${ }^{3}$ урынына // Татарстан. 1923. № 151.10 авг.

\section{I}

Карт композитор Эйхенвальд ${ }^{4}$ иптәш идарәсендә күптән түгел генә ясалып үткән татар симфония кичәсе 5 гомумән, татар музыкасы, кыйсмән ${ }^{6}$, аның киләчәге турында музыканы сөйгән күп кешеләрнең башында яңа фикерләр тудыргандыр дип беләм.

Чөнки хәзергә кадәр татар музыкасы безнең күз алдыбызда халык тарафыннан сакланып килгән хәлендә - табигый хәлендә генә тора иде. Бик күп жыр, моңнарның тарих көпчәкләре астында тапталып, югалып калулары, сакланган кадәрләренең татарларның инкыйразыннан соңгы изелү фажигаләре дәверенә гаид ${ }^{7}$ булуы турында сөйләп торасы да юк. Чит милләтләрнең татар жырларына, hәммәсе дә бер-берсенә охшаган, бертөрле, зарлы, моңлы аһәңнәр ${ }^{8}$, дип кыйммәт бирүләре дә, әлбәттә, шул ук сәбәптән.

Хәзергә кадәр күп фикерләр татар музыкасының киләчәге хакында гаять өметсез оеша килделәр. Югарыдагы иске күренешләргә карап, чит милләт кешеләренә дә, татарның үзеңә дә мондый фикер тууы гажәп түгел, әлбәттә.

Ләкин хөр милләтнең теле, әдәбияты, театр, музыкасы икътисади, сәяси шартларның үсүенчә үсә, киңәя барган кебек, мәдәниятнең үсеп килә торган башка тармакларына малик булган татар халкының музыкасы да бер көнне

\footnotetext{
3 Мөнакашә - сүз көрәштерү, тартышу, бәхәс, дискуссия; русча; "подробное изучение”, "обсуждение”; “дебаты”, “прения”, “спор”. (Йолдыз Исәнбәт иск.)

${ }^{4}$ Эйхенвальд - Антон Александрович Эйхенвальд (1875-1952), композитор, дирижер, этнограф.

5 Tатар симфония кичасе - Антон Эйхенвальд житәчелегендә Шәрык музыкасы симфоник концерты Казанда Кызыл Армия сараенда (Красноармейский дворец) (хәзер: Кәрим Тинчурин исемендәге Татар дәүләт драма һәм комедия театры бинасы) 1923 елның 3 августында үткәрелгән. Кара: Афиша Симфонического концерта Восточной музыки симфонического оркестра под управлением А. Эйхенвальда от 3 августа 1923 г.

${ }^{6}$ Кыйсмән - өлешчә, берникадәр, кисәкчә; русча: “частично” (Йолдыз Исәнбәт иск.)

7 Гаид - караган, бәйләнешле, бәйләнешле булган; русча: "имеющий отношение к чемулибо". (Йолдыз Исәнбәт иск.)

${ }^{8}$ Аһәң - аһәң; русча: “тон”; “гармония”; “мелодия”. (Йолдыз Исәнбат иск.).
}

бәлягатькә 9 ирешәчәгенә иман беркетелергә тиеш иде. Чөнки музыка - сәнгатьнең бер кисәге, сәнгать мәдәниятнең бер ботагы булып, бу соңгысы бары бөтен әгъзалары сәламәт булганда гына үсә, яши алачак. Татар мәдәниятенең башка тармаклары кебек аның сәнгате дә бер үк тарих күчәренә чолганып бармый хәле юк.

Менә бу соңгы фикер бездә беркадәр үзенең житәкчеләрен тапты һәм таба килә.

Соңгы елларны төрле жирләрдә таркалган көйләрне жыючылар, аны ноталар буенча язып беркетүчеләрнең табылуы татар музыкасын эзләү, тикшерү юлында беренче адым булса, музыка шинасы ${ }^{10}$ Солтан Габәшинең ${ }^{11}$ музыка назарияләре буенча, кыйсмән, татар аһәңнәреннән тукып яңа музыка әсәрләре бирүе, кайбер сәхнә әсәрләренә көйләр язуы, кайбер жырларны тавыш, үлчәү, басым кануннары буенча тикшереп, аларга күмәк жырлар оештыруы, шөбһәсез, икенче адым дип танылырга тиеш иде. Яшь музыкачы Сәйдәшевнең бу юлда хезмәт куеп ятканы да сәнгать тирәсендә чуалган эшчеләргә мәгълүм булса кирәк.

Ләкин бу адымнарның һәммәсе дә татар музыкасын мәдәниләштеру юлында хәлсез, ярым-йорты адымнар иде. Аларның төбендә татар музыкасын башка халыклардагы кебек гомуми аһәң кануннары буенча фәнни, ижади калыпка салу сизелсә дә, хакыйкатьтә ул адымнарның нык ышанычлы булмавы, кулланмаларның ажизлеге ${ }^{12}$ бик нык күзгә бәрелә иде. Бу, бәлки, безнең мөтәхассыйсләребезнең $^{13}$ бу хакта кирәгенчә назари, фәнни коралларга малик булмаганнан килгәндер.

Дөрест, бу юлда эшләп караучылар бер татарлардан гына булмады; төрле халыкларның музыкалары бер-берсеннән мәдәниятнең үзгә тармаклары төсле нык киртәләр белән аерылмыйча, алар арасында гомуми бәйләнешләр күп булганга, һәрбер мәдәни кавемнең (каумнең) ${ }^{14}$

\footnotetext{
9 Бәлягать - үсеп житү, русча - “достижение совершеннолетия”. (Йолдыз Исәнбәт иск.)

10 Шинас - оста, белгеч, русча: “знаток”, “специалист”. (Йолдыз Исәнбәт иск.)

${ }^{11}$ Солтан Габәши - Солтан Хәсәнгата улы Габәши (1891 - 1942), татар халкының көйязары (композиторы), педагог һәм музыкаль жәмәгать эшлеклесе.

${ }_{12}$ Ажизлек - зәгыйфьлек, камил булмау.

13 Мөтәхассыйс - белгеч; русча: "специалист" (Йолдыз Исәнбат иск.)

${ }^{14}$ Кавем (каум) - ыру, нәсел, кабилә; халык, милләт; русча: “племя”, “род”; “народ”, “нация” (Йолдыз Исәнбат иск.)
} 
музыкасы тәрәкъкый ${ }^{15}$ иткәндә, үз көче белән генә тәрәкъкый итүе тарихта күренми. Шуңар күрә француз музыкасын эшләүдә итальян музыкасы шинаслары никадәр киң мәйдан алып эшли алсалар, рус музыкасын да немец композиторлары авырлыксыз үзләштерә һәм аңар кыйммәтле хезмәт куя алалар иде. Бу гомуми кануннан, әлбәттә, без генә читтә утырып кала алмыйбыз. Без дә моны гажәпләнеп каршы алмаячакбыз.

Чынлап та, моның мисалы күз алдыннан үтте. Казанның Шәрык музыкасы белән яхшы таныш булган мәшһүр профессорларыннан Прохоров ${ }^{16}$ соңгы елларны бу хакта күп кенә хезмәтләр куеп карады. Ләкин нәтижәдә без татар моңының аңар баш июдән нык каршы торганын күрдек. Моңар, бер яктан, татар музыкасының гаять хам ${ }^{17}$, эшләнмәгән, чит халыкларның аңлаешы өчен читен бер хәлдә торуы сәбәп булса, икенче яктан, бу профессорның татар жырын мәдәниләштергән вакытта аның табигый, хосусый кануннарына игътибар итүдән бигрәк, аңа кидерелә торган Аврупа музыкасы шартларына, гомуми музыка техникасына күбрәк әһәмият бирүе дә сәбәп булса кирәк. Аның эшләгән көйләрендә татар жырының төп аһәңе гаять ялгыш чыга, ә кулланган гомуми техника бизәкләре асыл моңнарга ерак мөнәсәбәтле күренә иде.

Күптән түгел махсус кичәдә ижра(э) ${ }^{18}$ ителгән һәм композитор Эйхенвальд тарафынан эшләнгэн татар көйләрен тыңлагач, инде бу юлда да муаффәкыятьле ${ }^{19}$ тәжрибәләрнең барлыгы күренде.

Димәк, бу юлда тагын бер галәбә 20. Эйхенвальд башка милләттән булса да, куйган хезмәтләренә караганда, ул алган татар жыр-

15 Тәрәкъкыц - алга китү, прогресс; русча: “движение вперед”, “прогресс”. (Йолдыз Исәнбәт иск.)

${ }^{16}$ Прохоров - Яков Васильевич Прохоров (1870 1942), композитор.

17 Хам - чи, пешмәгән, өлгермәгән, эшкәртелмәгән; тупас; русча: “сырой”, “недоваренный”, “незрелый”; “грубый”. (Йолдыз Исәнбәт иск.)

18 Ижрра(э) - үтәү, эшкә ашыру, жиренә житкерү; русча: “совершение”, “выполнение”. (Йолдыз Исәнбат иск.)

${ }^{19}$ Муаффәкыять - уңыш, булдыра алучылык; русча: “успех”, “удача”, “достижение”. (Йолдыз Исәнбәт иск.)

20 Галәбә - жиңү, өстен булу, өстенлек; русча: “победа”, “превосходство”. (Йолдыз Исәнбәт иск.) ларының төп хосусыятьләрен ${ }^{21}$, аның төп моңнарын дөрест аңлаган. Аның жырларында татар моңы бик аз житешсезлек белән бирелә. Шуның өстенә ул төп моңны әсас 22 итеп алып, аны музика нәзарияләре ${ }^{23}$ буенча чуарлаганда, алынган жеп үзенең очын жуймый, төшерелгән бизәкләр төп материядән ераклашмый, кыскасы, аның иксез-чиксез кыллары, тавыш, басмалары арасында мөнәсәбәт өзелми; нәтижәдә исә «Салкын чишмә», «Туган ил» кебек, эшләнмәгән хәлендә яхшы ук бертөрлелек, ялыктыргычлык белән күзгә бәрелерлек көйләр, киенгән, ясанган, бизәнгән хәлдә матур булып күз алдына басалар һәм әллә никадәр кораллардан төзелгән зур симфониянең коточыргыч тавышлары астында нәкъ татарча гөрләп, бер бөтен тәшкил итәләр.

Дөрест, аның музыкасында да кытыршылар юк түгел; анда да әле техника тулы, кайбер урыннарда табигый аһәңне дөрес бирүгә уңгайсызлый төшә. Ләкин бит әле бу рәвештә татар моңын эшләү, әле, бердән, беренче тәжрибә диярлек, икенчедән, композиторның башка милләттән булуы да әз генә диккать ителерлек, өченчедән, жырларны ижра(э) итүче көчле оркестрда шул моңнарны жаны белән аңлый, үзләштерә алган бер генә татар да юк. Ләкин шунысы ачык: бу тәжрибә татар жырларының да киң сурәттә ${ }^{24}$ тәрәкъкый итә алуын, аларның да бәйнәлмиләл ${ }^{25}$ музика мәйданында техника ягыннан бик югары күтәрелгән Гареб [Көнбатыш] музыкасы мәйданында да оятка калмаслык калыпларга салына алачагын, тик моның өчен шунар бирелгэн мөтәхассыйслар $^{27}$, Һәвәскәрләр, мәктәп, оешмаларның гына кирәклеген ачык күрсәтте.

Инде алга бу юлдагы хезмәтләрне дәвам иттеру, алынган юлны киңәйтү мәсьәләсе килеп баса. Хәзер бер композитор килеп чыккан икән, аның белән бөтен мәсьәлә хәл ителеп бетә алмый, әлбәттә, һичбер сәнгатьтә, бигрәк тә

21 Хосусыять - үзенчәлек, аерымлык; русча: “частность”, “особенность”. (Йолдыз Исәнбәт иск.)

22 Әсас - төп, нигез; русча: “основа”, “фундамент”, “база”. (Йолдыз Исәнбат иск.)

${ }^{23}$ Нәзария - теория. (Йолдыз Исәнбәт иск.)

${ }^{24}$ Сурәт - рәсем, күренеш, кыяфәт, килеш, килбәт; русча: “рисунок”, “вид”, “образ”, “подобие”. (Йолдыз Исәнбәт иск.)

${ }^{25}$ Бәйнәлмиләл - халыкара, интернациональ; русча: “международный”, “интернациональный”. (Йолдыз Исәнбәт иск.)

${ }^{26}$ Гареб - Көнбатыш. (Йолдыз Исәнбәт иск.)

27 Мөтәхассыйс - белгеч, русча: “специалист". (Йолдыз Исәнбәт иск.) 
татар музыкасы кебек урыныннан кузгалмый яткан хам бер сәнгатьтә, бер генә кеше бик аз нәрсәгә жавап биреп китә алачак. Киләчәктә бу юлдагы хезмәтләрнең муаффәкыятьле чыгуы өчен бигрәк тә безнең үз музыкантларыбыз эшкә керешергә тиешләр. Монда Эйхенвальд иптәшнең хезмәте, аның алган юлы, минемчә, бу юлда эшләүчеләр өчен үрнәк булу хезмәтен итә алырга тиеш. Хәзергә кадәр татар музикасын эшләргә юл, сукмак эзләп тырышып яткан һәм үз юлларында күп хезмәтләр куйган Габәши, Сәйдәш ${ }^{28}$ кебек музыка шинасларыбызга Эйхенвальдның хезмәтләре зур жиңеллек ясарга тиеш. Әгәр дә бу юлда алар бергә аңлашып эшли алачак булсалар, бу бигрәк тә хәерле фал ${ }^{29}$ булачак һәм киләчәктәге эшләрнең тагын да нәтижәләрдә сәмәрәлерәк ${ }^{30}$ бирүен тәэмин итәчәктер.

Бу хакта күбрәк фикер алышу файдадан хали $^{31}$ булмас, hәм музыка сөючеләребез жиргә карарланырга да ижат мәйданын киңәйтергә керешерләр диясе килә.

\section{II}

Бу урында, әлбәттә, алдан өзеп китәргә тиешле бер мәсьәлә бар.

Без хәзер музиканы эшләү, ижат итү турында сөйлибез. Ләкин «бу музика кем өчен həм нинди булырга тиеш?» сөале алга баса.

Без моңа баштан ук боргаланмыйсыргаланмый гына «инкыйляби ${ }^{32}$ həм гаммә ${ }^{33}$ өчен» дияргә тиешбез.

Музика кешенең жанын тәрбияләүдә иң зур гамилләрдән ${ }^{34}$ санала. Көчле мөндәрижәле бер гыйльми бәхәстән кеше никадәр жан азыгы алып китә алса, яхшы эшләнгән, яхшы үтәлгән музика әсәреннән ул бигрәк тә тулы тәэсир белән китә.

${ }^{28}$ Сәйдәи - Салих Жамалетдин улы Сәйдәшев (1900 - 1954), күренекле татар композиторы, татар профессиональ музыкасына нигез салучы. (Йолдыз Исәнбәт иск.)

${ }^{29}$ Фал - бәхет, яхшы киләчәк, хәерлелек, яхшыга юрау; русча: "счастье”, “светлое будущее”; “предсказание”. (Йолдыз Исәнбәт иск.)

${ }^{30}$ Сәмәрәлерәк, сәмәрә - жимеш, нәтижә; русча: “плод”, “фрукт”; “результат”. (Йолдыз Исәнбәт иск.)

31 Хали - буш, эчендә бернәрсә булмаган; русча: "пустой"; мисал: беркем дошманнан хали булмас. (Йолдыз Исәнбат иск.)

${ }^{32}$ Инкыйляби - революцион; русча: “новаторский”. (Йолдыз Исәнбәт иск.).

${ }^{33}$ Гаммә - халык, масса; русча: “народ” (Йолдыз Исәнбәт иск.)

${ }^{34}$ Гамил - фактор, хәрәкәткә китерүче көч, сәбәп; русча: “фактор”, “причина”. (Йолдыз Исәнбәт иск.)
Адәмнең хиссиятен оештыру, рухи халәтен тәрбияләү хосусый мөһим урын тота. Безнең яңа нигездәге тормышта гаммәнең бу яктан тәрбиясе хосусый әһәмиятле урын тотачак.

Бигрәк тә, революциягә кадәр жыр-музиканы үзенең ачы язмышыннан зарлану, көенү хисләрен ныграк тышка чыгару өчен юлдаш иткән татар гаммәсен тәрбиядә аның әһәмияте зур булачак, һәм без моңа саклык белән, дикъкать белән карарга тиешбез.

Татар музикасының гражданлык алып сакланып килгән кадәресе киң өметсезлек, зар, фәган (фиган, фөган) ${ }^{35}$, тормыштан наразыйлык ${ }^{36}$ белән сугарылган. Бу - безгә шәфкатьсез тарихтан мирас булып калган хосусият. Башта Y3 ханнарының тәхет өчен көрәш корбаны булып яшәп, соңыннан урыс империализмының кызганыч фажигасе булган татар гаммәсе соңгы 3 - 4 йөздә үзенең рухын шундый ачы шәраблар белән генә сугарырга мәжбүр булган.

Ләкин хәзер ирекле яңа тормышның ирекле мәйданында бөтен хәят чишмәләренә бердәнбер хужа булып үсә торган халык балалары да, бәхетсезлеккә каршы, шул ук музиканы үзләренә мирас итеп алып калдылар.

Менә, пролетариат идеологиясе күзеннән караганда, безнең музикабызның бу хосусияте ирекле тормышның яңа шартлары белән ултырдаш, сердәш була аламы?

Хәзерге буынга хәят, ирек, житезлек, шатлык, бәйрәм, нәмаеш (нөмаиш) ${ }^{37}$ кирәк.

Ә безнең музыкабыз моны бирә алмый. Шуңар күрә киләчәктә татар музикасы өстендэ эшләүчеләр хакыйкать хәлнең бу ягына жиддият белән карарга тиешләр.

Әсасән, без, сәнгатьнең бөтен тармагындагы шикелле, музикави ижат эшендә халыкның үзенә якын булган ижатны алга сөрәбез. Театр, рәсем, шигырь, һәйкәлләр гаммәнең үз тормышыннан, үз эченнән алынып, аңар якын булган рәвешләрдә үсәргә тиешләр икән, музиканың да шул ук канун челтәренә керми хәле юк.

Бу жәһәттән без киләчәктә музика фронтында эшләгәндә, татар жырларын рәткә салганда, Гареб музикасындагы кебек, халыктан гаять ерак булган һәм индивидуумнарның хыялятын-

\footnotetext{
35 Фәган (фиган, фөган) - фарсы::“ачы тавыш”, ыңгырашу, "елау”, "үксү”; русча: "вопль”, “стон”, "плач", "рыдание”. (Йолдыз Исәнбәт иск.)

36 Наразый - разый булмау, канәгатьләнмәүче; русча: "недовольный”, "неудовлетворенный”. (Йолдыз Исәнбәт иск.)

${ }^{37}$ Нәмаеш (нөмаиш) - тантана; русча: “торжество". (Йолдыз Исәнбат иск.)
} 
нан $^{38}$ гына туган, яисә музиканың коры назарияләренә генә бина ителеп ясалган ысуллар кулланылып, гаммә белән музика арасындагы мөнәсәбәт ераклаштырылмасын, бәлки техниканың музикадагы өлеше гаммәнең жыр, музикаларын әсасән эшләүдә бизәк урынында торган кушымта ярдәмлекләр генә булсын дибез.

Бу шулай.

Без Эйхенвальд музикасында да бу фикергә муаффәкыять барлыгын әйтеп үттек.

Ләкин татар музикасының югарыда күрсәтелгән хосусияте безне монда да бик житди мөхакәмәдә ${ }^{39}$ булынырга мәжбүр итә.

Югарыда әйтелгәнчә, без бу назарияне турыдан-туры алга сөрсәк, татар музикасының һаман да ерактан ерак, тормыштан өлешсез, киләчәктән өметсез хәлдә алда басып калу куркынычы бар.

Татар жырлары арасында бу хосусияттән мөстәсна $^{40}$ булган бик аз санда такмаклар, бәетләр генә бар. Мондый жырларның иске заманда күп булып, тарихи сәбәпләр аркасында алар тормыштан төшеп, онытылып калулары, бара-бара эзләрен бөтенләй югалтулары никадәр мөмкин булса, аларның казылып чыгарылу ихтималлары шул кадәр имкяндан ${ }^{41}$ ерак тора.

Шуңар күрә киләчәктә безгә музиканың бу төрен үзебезгә ижат итәргә кирәк булачак.

Бу юлда да эзсез барырга туры килмәс. Чөнки, никадәр аз булса да, безнең хәят чаткысы күрелгән жыр, моңнарыбыз юк түгел. Бигрәк тә алар төрле жирдә, төрле формада, төрле калыптарак сакланып килгәннәр.

Киләчәктә музика шинасларының вазифасы менә мондый жырларны ныграк эзләү, тикшеру, алардагы тавыш, аһәң жырларын жентекләү һәм шуларның барыннан бербөтен тасвир $^{42}$ хасил итүдер. Шушы кисәкләр хисапка алынганда, аерым шәхесләр өчен аерым

\footnotetext{
38 Хыяләт - хыяллар; русча: “воображения мечты”. (Йолдыз Исәнбәт иск.)

39 Мөхакәмә - судта тикшеру, хөкем чыгару: бу очракта: тикшерү, фикер алышу; русча: "судебное разбирательство”, “вынесение приговора”. (Йолдыз Исәнбәт иск.)

${ }^{40}$ Мөстәсна - башкалардан аерып алынган, аерым, чыгарма; русча: “исключительный”, “из ряда вон выходящий”, “исключение”. (Йолдыз Исәнбәт иск.) 41 Имкян - мөмкин булу, мөмкинлек, булырлык хәлдә булу; русча: “возможность”. (Йолдызз Исәнбәт иск.)

42 Тасвир - ясалган сурәт, рәсем ясау, берәр эшне, хәлне, күренешне сурәтләп бирү; русча: “создание образа в воображении”. (Йолдыз Исәнбәт иск.)
}

ижатлар дөрес һәм муаффәкыятьле юлга салынырга мөмкин.

Бу вакыт, бу рәвештә музика әсәрләрен тудыруны халыктан ераклашу итеп алып та булмас. Чөнки төп нигездә аның үз малы салынганлыктан әсәрләрдәге форма гына аны халыктан ераклаштырып бетерә алмаячак.

Мондый әсәрләрнең халык тарафыннан жиңел үзләштерелүенә мәйданда берникадәр мисаллар да юк түгел. С. Габәшинең «Таһир Зөһрә» ${ }^{43}$, «Бүз егет»тәге ${ }^{44}$ берничә жырлары hәм берникадәр аерым көйләре аз гына бер вакыт эчендә хәзер халык эченә үз музикасы булып кереп бара. Габәшинең бу әсәрләрендә төп материянең саф татарныкы булмыйча, дөресрәге, татарга якын булган төрек, кыргыз, кырым татарлары моңнары да катнашкан булуы саф татар моңыннан төзелгән төрле көйләрнең бигрәк тә жиңеллек белән халыклашачагына дәлил була ала.

һәрхәлдә бу хакта житди фикер алышырга вакыт.

Бигрәк тә бу мәсьәләдә үз ижатларын матбугат битләреннән читтәрәк тотып өйрәнгән музика шинасларының үз фикерләрен ишетәсе килә.

Гаммәнең рухы, хисе, тәрбиясе нәүбәттәге ${ }^{45}$ мөһим мәсьәләләрдән.

Яңа тормыш, яңа шартлар ижат юлларының да яңаруын таләп итте.

Мәдәниятнең hәр тармагын кинәт күтәреп жибәргән Октябрь идеяләре музика мәйданын да почмакта асрарга риза булмаячак.

Инде моның беренче карлыгачларын күрдек. Калганнары да үз өстебезгә йөкләнгән.

\footnotetext{
43 «Tahup - 3өhрә» - Ф. Бурнаш трагедиясе (1917).

44 «Бүз егет»- К. Рәхим әсәре. (Йолдыз Исәнбәт uck.)

${ }^{45}$ Нәубәт - чират; русча: “очередь”, “ряд”. (Йолдыз Исәнбат иск.)
} 


\title{
ФӘННИ ШӘРЕХЛӘУ ЧЫГАНАГЫ БУЛАРАК НӘКЫЙ ИСӘНБӘТНЕН «ТАТАР МУЗЫКАСЫН ЭШЛӘУ ЮЛЫНДА» МӘКАЛӘСЕ
}

\author{
Йолдыз Нәкый кызы Исәнбәт, \\ mileuscha@mail.ru.
}

\begin{abstract}
Хезмәттә Нәкый Исәнбәтнең 1923 елда Казанда тәхәллүс белән басылган «Татар музыкасын эшләү юлында» дигән мәкаләсенең текстологик, фәнни шәрехләреннән гыйбарәт. Аны галим Гражданнар сугышы елларында хәбәрсез югалган өлкән абыйсының истәлегенә багышлый. Мәкаләдә Нәкый Исәнбәтнең фикерләре безнең көннәрдә дә үзенең актуальлеген югалтмаганлыгы ышандырырлык итеп исбатланган. Галим татар халык музыкасын өйрәнүдә төп тенденцияләрне дөрес билгели алган һәм профессиональ татар музыкасын үстерү юлларын ачыклаган.
\end{abstract}

Төп төшенчәләр: татар музыкасы, татар халык жыры, Нәкый Исәнбәт, А. А. Эйхенвальд, С. Габәши, С. Сәйдәшев. 